\title{
Morphology of Warsaw City Structure Using Urban Indexes and GIS Tools
}

\author{
Anna Małgorzata Jachimowicz (D)
}

check for updates

Citation: Jachimowicz, A.M. Morphology of Warsaw City Structure Using Urban Indexes and GIS Tools. Land 2022, 11, 135. https://doi.org/10.3390/ land 11010135

Academic Editor: Martina Koll-Schretzenmayr

Received: 22 November 2021 Accepted: 11 January 2022

Published: 15 January 2022

Publisher's Note: MDPI stays neutral with regard to jurisdictional claims in published maps and institutional affiliations.

Copyright: (C) 2022 by the author. Licensee MDPI, Basel, Switzerland. This article is an open access article distributed under the terms and conditions of the Creative Commons Attribution (CC BY) license (https:/ / creativecommons.org/licenses/by/ $4.0 /)$.
Faculty of Architecture, Warsaw University of Technology, Koszykowa St. 55, 00-659 Warsaw, Poland; anna.jachimowicz.dokt@pw.edu.pl

\begin{abstract}
The article presents the process of creating a tool using GIS systems to describe the city's spatial structure. Therefore, the subject of this research was the method of describing the city structure using non-functional zoning, in conjunction with the use of urban indicators. Using the relationships between the values of urban indicators and individual typologies of buildings, they can be assigned to subsequent zones from the Rural-to-Urban Transect methodology. Therefore, in this article, urban indicators have been defined, thanks to which it is possible to distinguish different typologies of buildings. Next, the relationships between selected indicators and transect zones have been examined, and thanks to the obtained conclusions, transect zones for Warsaw have been defined. Finally, the spatial structure of a selected part of Warsaw has been described using these zones. The purpose of this study is also to initially assess the usefulness of the developed tool for the needs of urban planners.
\end{abstract}

Keywords: rural-to-urban transect; urban morphology; urban zones; urban indexes; GIS analyses; modelbuilder application

\section{Introduction}

A structure is a whole, a system consisting of interrelated elements [1]. Thus, the city as a structure consists of parts or components that have specific relationships. In their work, urban planners often divide the city structure into a functional structure that describes the functions of objects or the purpose of areas and a spatial system that they describe as a physical form of a given space [2]. In the spatial approach to the city structure, one can speak of a form or "solid-spatial configuration" [3], in which the components are primarily buildings and spaces between them. Considering both types of these structures in the context of the city as a whole, it is easier to identify individual functional areas in the city than to examine in detail the spatial form of each city block.

In the context of this research, it is crucial to understand the spatial structure of a city defined from partial spatial structures-phenomena, subsystems, also called layers [4]. According to Fiedorowicz, listing all its components may be a specific difficulty in determining the spatial structure of a city [5]. Therefore, when describing the city, some simplifications of its structure are made, i.e., modeling, and the simplified image of the city itself is called its model. In such a model of the city's spatial structure, the main elements that build it are distinguished, and the relations between them are described.

In spatial planning, zoning is also a frequently used concept. Like structure, it is understood as the division of a given area into smaller, characteristic areas or zones [6], distinguished by a set of specific criteria. Podolak points out that the criteria for zoning may relate to the permissible type of function, the manner of shaping buildings, the diversification of the intensity of space use, the standard of open spaces, or other standards determining environmental conditions [7]. Taking into account these criteria, several types of zoning can be distinguished. Such a division was presented by Drzazga [8], in which he listed the division into two basic types of zoning and four subtypes: classical, flexible, 
overlay and special areas. In such a distinction, taking into account the research subject, the most important will be the division into subtypes. The first one, i.e., classical zoning, is the delineation of zones for individual land-use methods, so it is simply the designation of functional zones, e.g., residential, commercial, industrial, etc. Drzazga indicates that this type of zoning is currently being questioned in more flexible regulations [8]. The second subtype, i.e., flexible zoning allows for more diverse forms and types of spatial development compared to the only functional criteria of classical zoning. Drzazga also points out that with this type of zoning, the local authorities have the ability to better react to rather dynamic changes in the market pursuit for useful space.

Various forms of such zoning are mentioned, but this study will approximate zoning by standards, otherwise known as performance zoning or guiding development. In their works, Zuziak [9] and Podolak [10] list the principles on which this zoning is based. Particular attention should be paid to the principle that each type of land use may be located at the junction of another type of use, provided it meets the relevant criteria and standards set out in a given regulation. This principle is also often used by urban planners during the inventory of areas where functional fragmentation into small areas often occurs, while the division into forms and volumes of buildings is not distinguishable. Then such an area belongs to the previously selected types of zones, e.g., low-rise building zones. The second principle in this zoning consists of assessing and assigning a site to a given zone based on an analysis of its features and the characteristics of its surroundings, not a predetermined functional classification.

\subsection{Types of Urban Standards and Indexes}

These features mentioned above are related to the standards, which in turn are a kind of measures/indicators. These standards, in performance zoning, are the focal point of regulation and can be divided into five categories:

1. density standards, building intensity, building coverage, etc.

2. resource protection standards

3. standards for open spaces

4. ecological standards

5. standards of urban and urban-architectural design, e.g., the size of plots, the maximum height of buildings, building proportions.

Drzazga also points out that standards are one of the most important tools for shaping urban space [8]. Following Grudziński, the urban standard can be described as an inventoried state of development of a certain space [11]. Sumień lists the following standards among his works: "social and technical infrastructure, location, density, intensity, and environmental".

An often interchangeable concept with the standard is the urban index. Sources provide many indexes that affect the spatial structure and development of cities. Many of these were often tested by urban planners in terms of the correlation of the value of one indicator with the values of other indicators [12]. Selected indicators that have the most significant impact on the shaping of the city structure were systematized into four groups by Ziobrowski in 2012 [13]. The first group includes indicators of balancing the natural environment, the second is indicators of shaping the spatial structure, the third-the functioning of the spatial system, and the fourth is indicators of shaping buildings. The indicators of shaping the city's spatial structure and development of buildings are the most important indicators in the context of this research.

The indicators mentioned in the list by Ziobrowski are mainly used when conducting research on the existing city structures-in their inventory, searching for relationships, e.g., between the type of buildings and the values of indicators, or between the location of the facility in the city structure and its value on the real estate market.

Therefore, the search for a method of describing the city structure using zoning, other than functional zoning in conjunction with urban indicators has become the subject of this research. For this purpose, it was decided to delve into two methodologies for describing 
the city structure, which began to appear in the scientific literature from the beginning of the 21st century. They are presented below in Section 2.1.

\subsection{Structure of the Article}

The article is divided into the following parts:

1. Introduction with a review of the literature on the methods of describing the spatial structure of the city and selected classifications of urban indicators;

2. The methodological context in which two methods of space description were introduced, based on the gradation of buildings, which were the basis for constructing the original GIS tool based on both of them. This part presents the purpose of the work in more detail.

3. Section 3 presents the spatial scope of the study, the process of obtaining the necessary spatial data for analyses, the detailed process of building the tool in the GIS environment, and a description of selected urban indicators.

4. In the results, the first part describes the relationships between the values of indicators and the allocation of building quarters to the transect zone. Then, based on these relationships, a transect urban cross-section for Warsaw is presented. The second part of this chapter shows the effect of the GIS tool used to describe a selected part of the city of Warsaw.

5. The last chapter presents a summary and an assessment of the tool's operation in terms of its usefulness in urban planners' work.

\section{Methodological Context}

\subsection{Transect and Spacemate-Similarities and Differences}

There is no shortage of studies in the literature on the relationship between the values of individual urban indexes and the form of development. There is a well-known example showing various typologies of buildings while maintaining the same intensity value $[14,15]$. Perhaps the best-known tool for presenting the density of an urbanized environment is the "spacemate" developed by Meta Berghauser Pont and Per Haupt at the beginning of the 21st century. [16-18]. Spacemate shows the building intensity and built-up area on one graph. Thanks to this, it is possible to observe the relationships between these indicators and the form of buildings. Different typologies of buildings will be located in different parts of the chart. The authors in their book [18] show different types of buildings depending on the value of urban indicators and name these forms (Figure 1). They describe the differences between them and indicate the forms ranging from the most urban, through typical quarters of urban development, development of garden cities, to suburban buildings of various densities. They also indicate typologies of buildings with low development intensity and a high number of stories, which break out of the hierarchy, which they call "park" typologies, due to the large open green areas between the buildings. The "park" typology is also present in Warsaw's blocks of flats, mainly prefabricated ones, often called housing estates by town planners or simply "blocks" by residents.

The gradation and systematization of various building typologies is also the basis of the urban-to-rural transect (hereinafter: transect) methodology introduced by Andreas Duany from the DPZ CoDESIGN (Duany \& Plater-Zyberk architectural practice) [19]. Transect defines a number of zones where the development gradation takes place from typical country houses to the densely built-up city center, often called the urban core. Transect, called by Domińczak as an urban profile, is both an analytical method and a planning strategy [20]. It is a comprehensive system of space organization that organizes the built environment in a way that takes into account the integration of urban and rural environments, with a variety of typologies [21]. As a result of the evolution of the use of this tool to describe the existing development structures, a number of zones with values of urban indicators similar to the basic zones but representing amorphous, monofunctional building structures, i.e., zones S1-S7, have been added to the division into T1-T6 zones (Figure 2). 

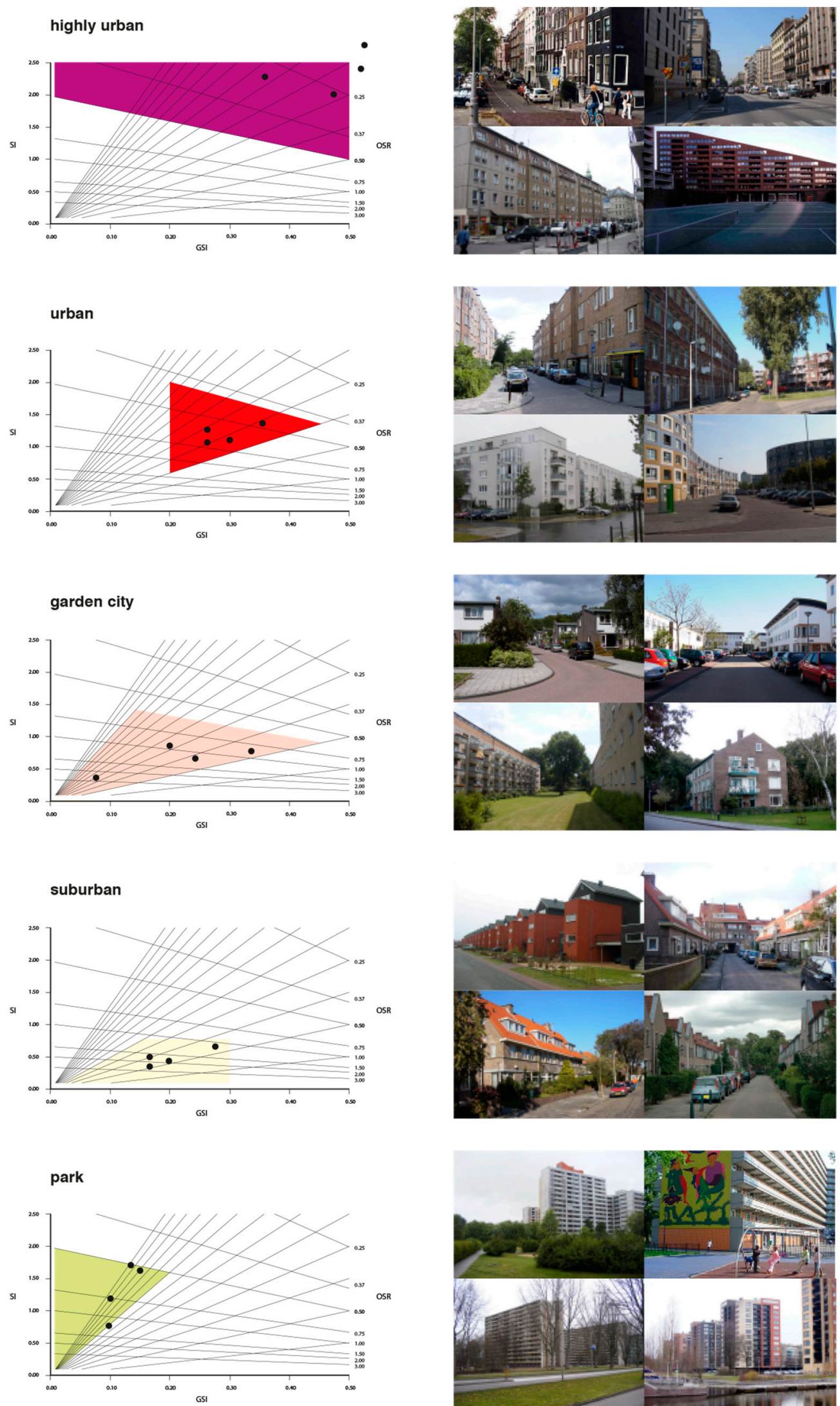

Figure 1. Types of buildings in Space matrix. Source: [18]. 

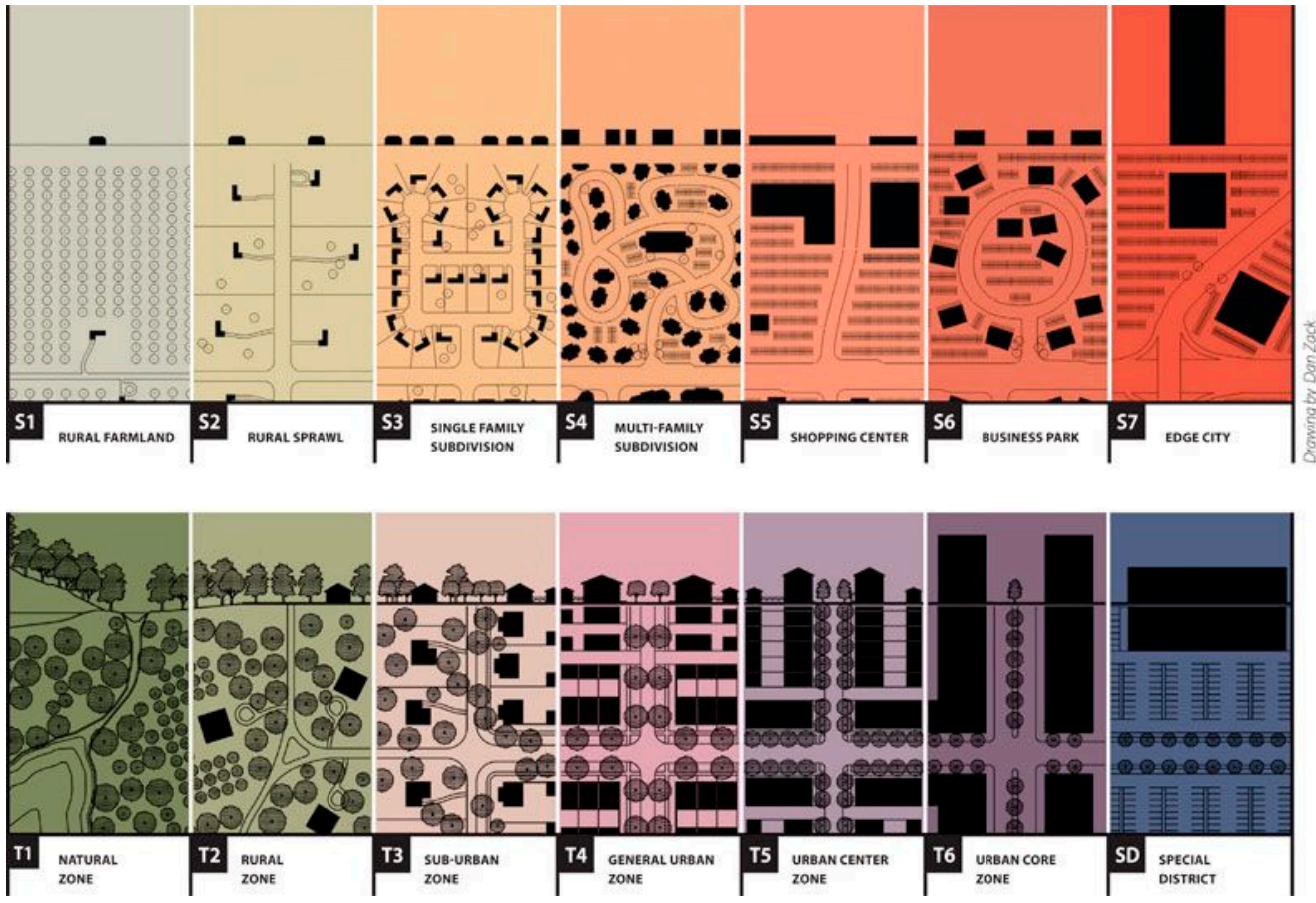

Figure 2. Transect in New Urbanism and in Urban Sprawl; T.Hass, "NewUrbanism and Beyond" Rizzoli, 2002, p. 216.

Although both tools have been used since the beginning of the 20th century and have common features, their authors do not refer to each other. Some speculation in the differences between these tools may be that the spacemate tool is used to study existing building structures, while the transect finds its use mainly in the preparation of guidelines for organizing and shaping the development of buildings, which are assigned the so-called SmartCode [22,23]. Transect, as a tool for describing space, appears in many sources [24-27], similarly to the related smart codes, which codify the form of the city's tissue [28-30].

Therefore, this article attempts to define the transect zones for the city of Warsaw using the values of selected urban indicators in the city area selected for analysis. The aim of this study is also to find and indicate the dependencies, similarities, or differences between the two methods and a preliminary assessment of the usefulness of the tool built for the needs of urban planners.

\subsection{GIS as a Spatial Structure Analysis Tool}

Due to the need to examine the value of several urban indicators for each selected single field unit and find potential relationships between them, it was decided to conduct the research in the geographic information system (GIS) environment. Conducting urban research and analyses with the use of spatial information systems has been growing since the 1960s [31]. The use of GIS in urban and spatial planning is becoming more and more popular as they are undoubtedly tools that facilitate the work of urban planners and architects [32]. GIS systems enable the collection, processing, analysis, visualization and sharing of spatial data [33] and their primary function is to support decision-making [34]. Among others, the Polish Institute of Urban and Regional Development conducted research on the decision support process using GIS tools [35]. No wonder that after 2000 they have been widely used in the work of town planners, planners and more and more often, also architects. GIS systems have become the basic tool in spatial research, the results of which may be helpful in the preparation of planning studies, i.e., local spatial development plans or studies of the conditions and directions of spatial development [32]. In the literature, we can find many examples of the use of GIS in such analyses, including determining the maximum allowable height of newly designed buildings [36], assessment of the city sprawl 
based on land use analysis using GIS and remote sensing [37], identification of areas for new investments [38], analysis of building layouts [39], land absorption analysis with the use of GIS [40], the study of the impact of building morphology on energy consumption [41], construction of a spatial database as a tool for participatory activities [42] and many others.

\subsection{Research Purposes}

This article shows a parametric approach to the description of the city's spatial structure. The research presented in the paper aims to describe the spatial structure of a selected test part of the city of Warsaw with the use of the rural-to-urban transect tool adapted to the specificity of the development of Polish cities. This tool consists of homogeneous development zones distinguished in the urban landscape, characterized by a gradation of buildings from more rural forms, through suburban ones, to various types of urban development [43]. Therefore, mathematical relationships between individual typologies and the values of urban indicators were researched, thanks to which individual units were classified as a given development zone. Taking into account that the areas selected for the analysis are located in different parts of the city, it can be assumed that all of the transect zones pre-selected for Warsaw may be located within their borders. Due to the necessity to examine the value of several urban indicators for each individual field unit and find potential relationships between them, it was decided to conduct research in the GIS environment. As a result, the application of this tool in the test area can be helpful in the analysis of subsequent parts of cities or their entirety, because the model once built can be used for subsequent analyses in an identical or extended form.

The aims of the article are a transect description of the spatial structure of a selected part of the city, an examination of how the transect zones change depending on the value of urban indicators, and building an algorithm based on these dependencies in the GIS environment, which will enable a digital description of the city's spatial structure as morphologically homogeneous development zones.

The article shows the use of the Transect and digital methods that support city planners in the context of describing the city morphology. The research part of the thesis shows the process of building a complex geoprocessing tool used to calculate urban indicators. On the basis of the relationship between the values of these indicators, groups characterized by similar features were distinguished, while these groups constitute different typologies of buildings found in the urban structure of the city.

\section{Materials and Methods}

\subsection{Description of Study Area}

The research described in this article was conducted for the area in the eastern part of the Ursynów district, in the vicinity of the Warsaw University of Life Sciences and the Vistula escarpment. Individual quarters of buildings throughout Warsaw were selected for the simultaneous partial research aimed at identifying and verifying the values of urban indicators that determine the allocation of individual quarters of buildings to the transect zone. These are single city blocks, called test quarters, which are limited by public roads or other forms of development, e.g., forests, parks, waters. To be sure that at least one-quarter of buildings will be assigned to each of the transect zones, almost 50 areas were selected for the study. The spatial scope of the actual study and the location of the test quarters in the city space is illustrated below (Figures 3 and 4). 


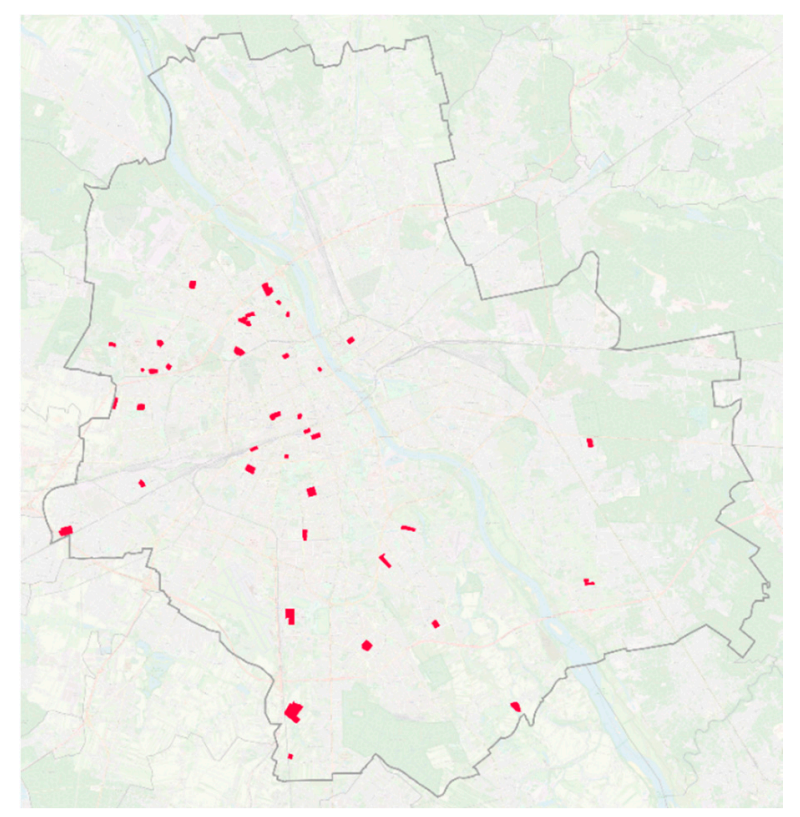

Figure 3. Locations of test quarters in the area of Warsaw. Source: own study.

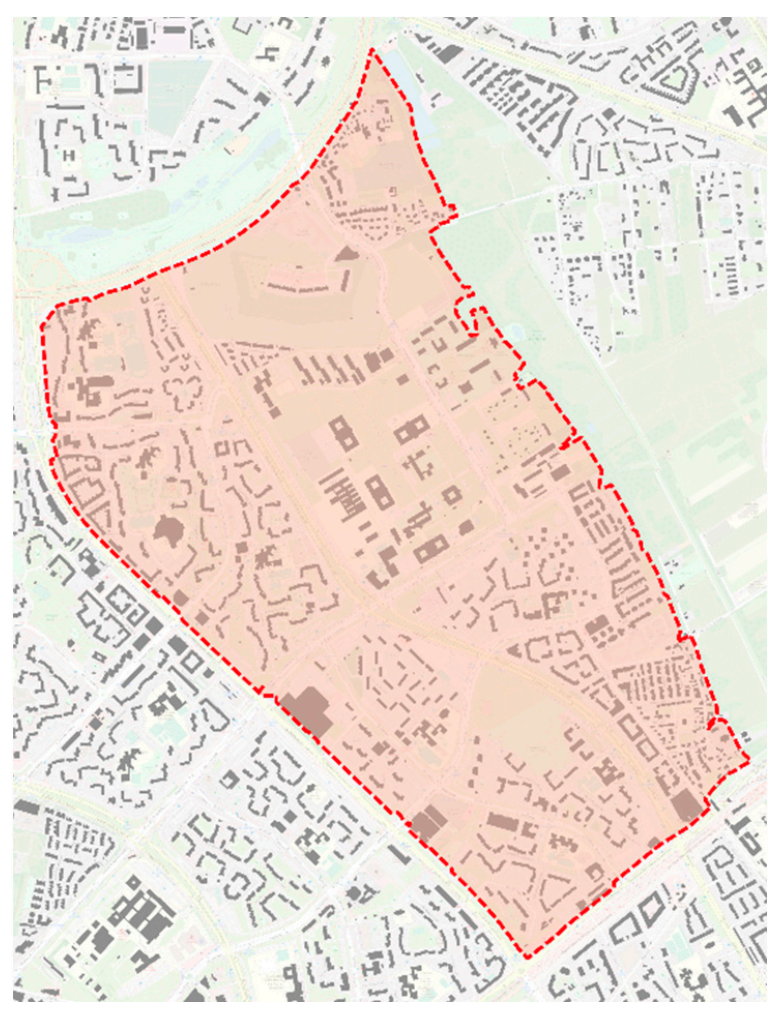

Figure 4. The area of actual analyses. Source: own study.

\subsection{Data Collection-Source of Data}

The main objective of the study was to describe the spatial structure of a selected part of the city with the use of tools based on spatial relationships between individual elements included in a given image of this part of the world. Such possibilities are provided by geographic information systems (hereinafter GIS) [44], in which a given part of the world is described by means of overlapping layers with information about its various components, e.g., waterways, building blocks, buildings, streets, etc. The advantage of such a description of a fragment of reality, is the possibility to find spatial relationships between objects from 
several layers, e.g., if you have overlapping layers of buildings and quarters, you can indicate which of these quarters are covered with buildings to the greatest extent. It is also the definition of the urban coverage index (\% PZ) used in urban and spatial planning. In order to calculate the values of this and other urban indicators described later in the article for each individual quarter of development in a selected area with the use of GIS systems, it was necessary to obtain spatial data and verify the relevance and usefulness of the relevant attributes.

For the purpose of analyses, the spatial data was obtained mainly from the so-called "open sources" that are made available to users free of charge. The data on the buildings was obtained from the Land and Buildings Register (hereinafter referred to as EGiB) [45,46], which has attributes with information about the number of stories of individual buildings and also about their basic function. Data on land development functions, protected areas, street axes, and main public spaces come from the Open Street Map database (hereinafter OSM) [47], and the Database of Topographic Objects (hereinafter BDOT 10k) [48]. The relevant content layers from these two databases have been verified, cut and adjusted, so the input layers for the analyses are comprehensive and complete.

For the analyses described in more detail later in the article, urban planning indicators were selected at the onset; these can be described mathematically: the percentage of building coverage, the density of development, the weighted average number of stories, the number of stories predominant in the quarter, and the age of buildings in the quarter. These indicators were selected based on the author's previous experience working on the Transect research. The list of indicators and the necessary layers with spatial data is presented in Table 1 supplemented with the necessary attributes that each layer must have in order to build a correct tool and the source of the data.

Table 1. Selected urban indicators for analysis. Source: own study.

\begin{tabular}{|c|c|c|c|}
\hline $\begin{array}{l}\text { Quantitative Urban } \\
\text { Index }\end{array}$ & $\begin{array}{l}\text { Required Layers } \\
\text { with Spatial Data }\end{array}$ & Required Attributes & Data Source \\
\hline \multirow[t]{2}{*}{$\begin{array}{c}\text { Percentage of } \\
\text { building coverage }\end{array}$} & Buildings & Building area, building age & Own study based on EGiB \\
\hline & Quarters & $\begin{array}{l}\text { Area of the quarter, the dominant } \\
\text { function in the quarter }\end{array}$ & $\begin{array}{c}\text { Own study based on EGiB (layer } \\
\text { developed as part of the work on the } \\
\text { analysis of the absorptive capacity of the } \\
\text { city of Warsaw) } 1\end{array}$ \\
\hline \multirow[t]{2}{*}{ Building density } & Buildings & $\begin{array}{l}\text { Building area, number of stories, } \\
\text { building age }\end{array}$ & Own study based on EGiB \\
\hline & Quarters & $\begin{array}{l}\text { Area of the quarter, the dominant } \\
\text { function in the quarter }\end{array}$ & $\begin{array}{c}\text { Own study based on EGiB (layer } \\
\text { developed as part of the work on the } \\
\text { analysis of the absorptive capacity of the } \\
\text { city of Warsaw) }\end{array}$ \\
\hline $\begin{array}{l}\text { Maximum elevation } \\
\text { in the quarter }\end{array}$ & Buildings & Number of stories & EGiB/BDOT10k \\
\hline $\begin{array}{l}\text { Weighted average } \\
\text { number of stories }\end{array}$ & Buildings & Building area, number of stories & EGiB/BDOT10k \\
\hline $\begin{array}{l}\text { Predominant age } \\
\text { of buildings }\end{array}$ & Buildings & Year of construction & $\begin{array}{c}\text { Own study based on EGiB (layer } \\
\text { developed under a grant) }\end{array}$ \\
\hline
\end{tabular}

\subsection{Data Processing and Analysis/Creation of a Model Builder in GIS}

The first step in building the tool (Figure 5) in the ModelBuilder application in ArcGIS was to ask the question of what the output of this model is supposed to be. In the first part of the research, the result was to be the spatial layer with the quarters of buildings for which the values of urban indicators selected for these analyses will be calculated. These analyses, in order not to yield biased results, should be carried out with the exclusion of 
areas that do not represent typical transect zones. Therefore, modules 3-7 and 9-11 use appropriate geospatial tools on the verified, structured and adapted input layers (modules $1,2,8)$ to select the areas that belong to:

1. the so-called special zones-industrial and production areas, technical infrastructure, areas with buildings and large-area commercial facilities;

2. natural or partially natural zones-forests, parks, waters, protected areas, areas not impacted too much by man, but also the areas of allotments;

3. public zones-areas with public facilities—schools, kindergartens, hospitals, churches, buildings with a cultural function;

4. communication zones-roads, road, rail and air transport.

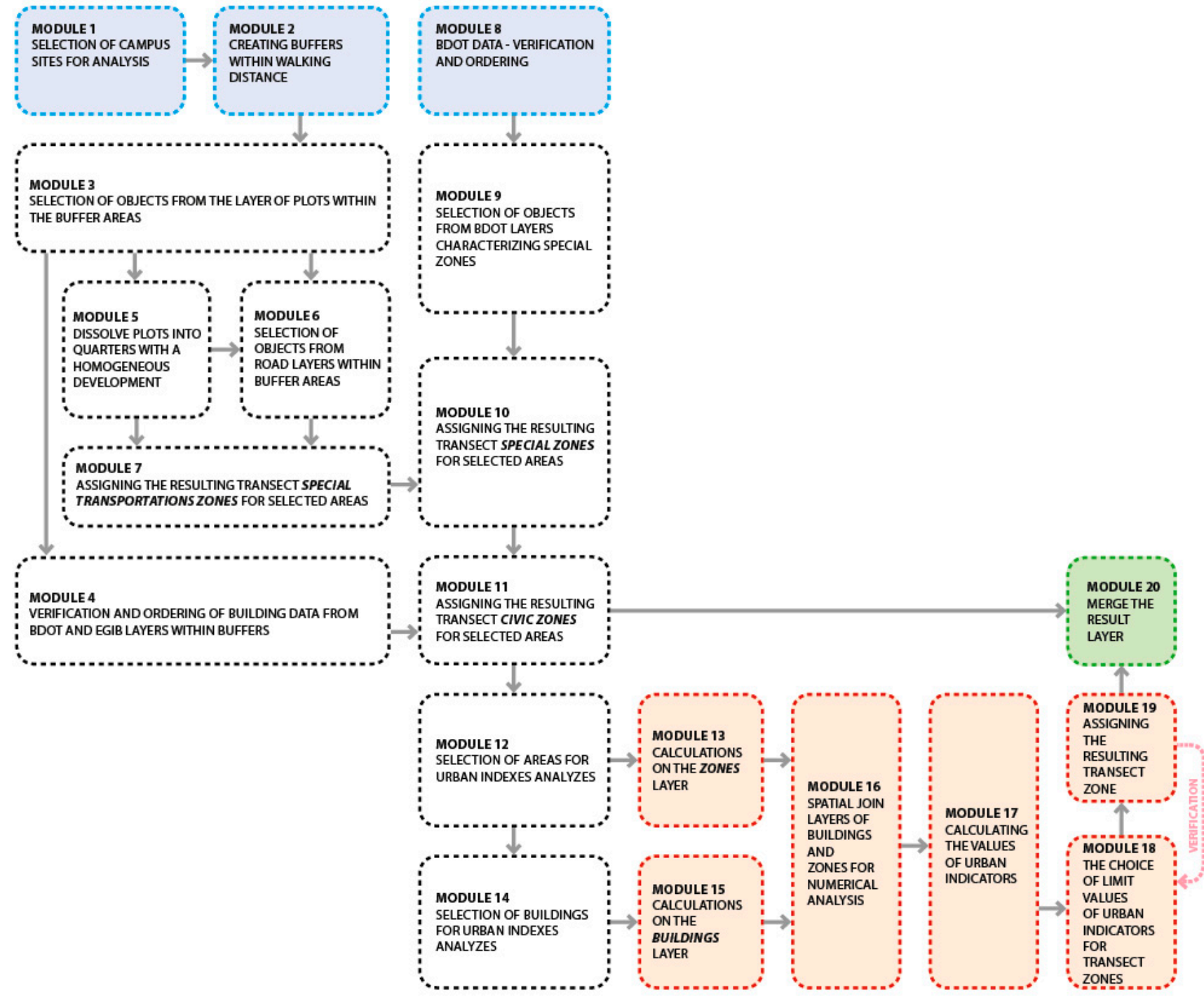

Figure 5. A simplified diagram of developing the tool to describe the spatial structure of the city. Source: own study.

The remaining areas, which were not assigned to any of the above categories, were exported to a new spatial layer. For further analyses, a layer with buildings located within the selected areas was also required. In order for these layers to be useful in the main part of the research, the first step was to check if they had key data fields in the layer's attribute table. For the terrain layer, the key information is the surface area, as most of the indicators (modules 12 and 13) relate to it. The layer with buildings should contain information on the area occupied by the building (i.e., the building coverage), the number of above-ground 
stories, the total area of the building (i.e., the product of the built-up area and the number of stories) and the age of the building (modules 14 and 15). Once properly prepared, these layers served as input data to create an overlay using the SpatialJoin tool, called for the purposes of this article the "calculation layer" (module 16). The area from the input layer is an overlay of this layer, but each is already assigned with information about the total building area in a given quarter, the total area, the maximum height of buildings, and the dominant age of the buildings. After these preliminary calculations, it was possible to carry out the previously selected analyses of quantitative urban indicators (module 17) described in detail in the following subchapters.

\subsubsection{Percentage of Building Coverage in a Quarter}

The percentage of building coverage of a quarter is expressed by the ratio of the built-up area [49] to the area of the quarter (1):

$$
\% P Z_{n}=\frac{\sum_{i=1}^{k} P Z}{P Q_{n}} \times 100 \%
$$

where:

$\% P Z$ - percentage of building coverage of a quarter

$P Z$-built-up area

$P Q$ - surface area of the quarter

$n$-number of the quarter

$k$-number of buildings in the n-quarter

The indicator in the above form takes values in the range [0; 100]. The minimum value of the index occurs when there are no buildings or structures in the quarter. High values of the discussed parameter prove the considerable use of the area of the quarter for development. The maximum value-100 - will occur relatively rarely and will indicate the full use of the quarter for development. In such situations, the built-up area equals the area of the quarter $(P Z=P Q)$.

\subsubsection{Building Density in a Quarter}

According to the Ordinance on technical conditions to be met by buildings and their location, the density of development is the ratio of the total building area to the plot area. In turn, the total area is the product of the built-up area and the number of stories, both above-ground and underground. For the purposes of this study, the building density index is calculated only for the above-ground stories, as it is the above-ground part of the building that determines whether it belongs to a given typology. In addition, information on the number of underground stories is not available for all buildings, and therefore using them only in a few cases could introduce statistical errors in the results and disturb the distribution of the indicator values in individual intervals.

Therefore, the density of buildings can be expressed as (2):

$$
\mathrm{INT}_{n}=\frac{\sum_{i=1}^{k} P C_{n}}{P Q_{n}}=\frac{\sum_{i=1}^{k} P Z_{i} \times l k_{i}}{P Q_{n}}
$$

where:

INT-building density

$P C$ - total area of the building

PZ-built-up area

$l k$-number of above-ground stories of the building

$P Q$ - surface area of the quarter

$n$-number of the quarter

$k$-number of buildings in the n-quarter 
In the above form, this indicator will take the values $[0 ; \infty)$. In fact, the maximum value of this coefficient may be equal to the number of stories of a building when the following conditions are met: the area of a quarter will be equal to the built-up area and when the building is one block with one value of the number of stories. On the other hand, the minimum value will occur when there is no building in a given quarter. In fact, the values of the building density coefficient will differ in different parts of the city, due to different typologies of the buildings and the period of their construction. The lowest value of the coefficient is characteristic for the areas of extensive single-family housing, while the highest is for compact downtown high-rise buildings.

\subsubsection{Weighted Average Number of Stories}

Another known quantitative indicator is the average weighted number of stories. Similar to the previous parameter, it may indirectly indicate the degree of land development, because it depends on the total area of the objects and their built-up area. The spatial distribution of this indicator-similarly to the previous one-will not assume a concentric system, the epicenter of which would be in the city center, and the lowest values only on its outskirts.

The weighted average number of stories for a given quarter can be expressed by the ratio of the sum of the total area of buildings in a quarter to the sum of their built-up areas (3):

$$
\text { sr.l. } k_{n}=\frac{\sum_{i=1}^{k} P C}{\sum_{i=1}^{k} P Z}=\frac{\sum_{i=1}^{k} P Z_{i} \times l k_{i}}{\sum_{i=1}^{k} P Z_{i}}
$$

where:

sr.l.k.-weighted average number of stories

$P C$ - total area of the building

PZ-built-up area

$n$-number of the quarter

$k$-number of buildings in the n-quarter

The values of this indicator will be in the range $[1 ; \infty)$. The lowest possible value, i.e., 1 , will occur when the sum of the total area in a quarter is equal to the sum of the built-up area. The highest values of this coefficient will occur in areas with relatively high buildings in small quarters.

\subsubsection{Maximum Elevation of Buildings}

The height of buildings can also indirectly affect the degree of land use. The areas of city centers and city hubs will be characterized by a higher value of the building elevation than the areas of suburbs. Nevertheless, the spatial distribution of this indicator will not assume a concentric system with high values in the center and low values at the city limits. Urban sprawls grew in various ways, often absorbing smaller towns or settlements as well as organized rural structures. Therefore, in the spatial distribution of the phenomenon, there will be local increases in the value of this indicator. In geostatistics, such areas are called hot spots for a given phenomenon. In fact, these will be areas of district centers or housing estate hubs, often located near communication points, e.g., train stations or metro stations. Such a distribution of higher buildings, and thus often areas with a higher value of the building density coefficient, is identical with the TOD principle-transit oriented development. This method, developed in the United States, consists in locating more urbanized and compact areas in the immediate vicinity of public transport points, most often rail (high-speed rail station, subway station, or suburban train station). Higher values of the number of stories and the density of development will also result in the allocation of quarters with such buildings to the higher transect zones. Therefore, this coefficient can be represented by the Formula (4):

$$
\max H_{n}=\max H_{\in}\left(H_{1}, H_{2}, \ldots, H_{k}\right)
$$


where:

$\max \mathrm{H}_{n}$-the maximum value of the number of stories in this area around the TOD point $\left(H_{1}, H_{2}, H_{3}, \ldots H_{k}\right)$ - a set of possible values for the number of stories in a given area around the TOD point

\subsubsection{Predominant Age of Buildings}

The previously discussed indicators related directly to the quantitative properties of buildings in the analyzed quarters. Another indicator, which can be said to be more qualitative or descriptive, is a kind of guarantee of selecting areas in the results of analyses that are not characterized by a simultaneous increasing gradation of the previously described urban indexes. These are the areas of the so-called housing estates built in the years 1958-1990. Therefore, in the analysis of the building age, the buildings were divided, and then the quarters of buildings were divided into three groups: those built before 1958, in the years 1958-1990, and after 1990. The relationships between the age of buildings and the indicators have been described and commented on in more detail in the results of the study.

\section{Results}

\subsection{Study of the Correlation between the Values of Urban Indexes and Transect Zones}

As a result of the algorithm, module 17 created a layer containing information on the values of selected urban indexes assumed in each individual area. The graphic image of this layer can be five diagrams, each showing the spatial distribution of a different indicator. Their juxtaposition allows drawing preliminary conclusions as to the values of indicators that should characterize individual transect zones (module 18). Additionally, using the same tools as in module 17, the values of indicators for selected test quarters were calculated. In order to show the relationships between the indicators and to select the optimal limit values of the indicators for individual zones, the obtained data is presented in the diagrams below.

The ordinate axis (Figure 6) shows the values of the development density parameter, while the abscissa is the percentage of building coverage. This is the "spacemate" chart mentioned in chapter two [16-18]. It presents directly the values of these urban indexes for selected test quarters and enables the examination of the form of development indirectly in relation to the density of buildings. The individual areas on the chart correspond to different morphological types, thanks to which "spacemate" enables the comparison of selected quarters of buildings with a similar density of development, but with different typologies. In carrying out their research, Berghauser and Haupt revealed the relationship between urban features, i.e., higher surface area and building density parameters, and its form. Additionally, lines were drawn from point 0.0 showing the average weighted number of stories of buildings. The lines that divide buildings into height types adopted in the Polish construction law [50] are marked in red, namely:

- low-rise buildings - up to $12 \mathrm{~m}$ high, corresponding to an average of four stories,

- $\quad$ medium-high buildings-12-25 m/4-8 stories,

- tall buildings-25-55 m/8-18 stories,

- $\quad$ high-rise buildings-over $55 \mathrm{~m}$, i.e., over 18 stories.

Such relationships can also be read from the chart above for the test quarters in Warsaw. Identified individual typologies of buildings are captured in Figure 7. After their identification, there was also a noticeable relationship between the distribution of individual types of buildings in the spacemate matrix and their assignment to transect zones. 


\section{Distribution of INT and \%PZ values for test quarters}

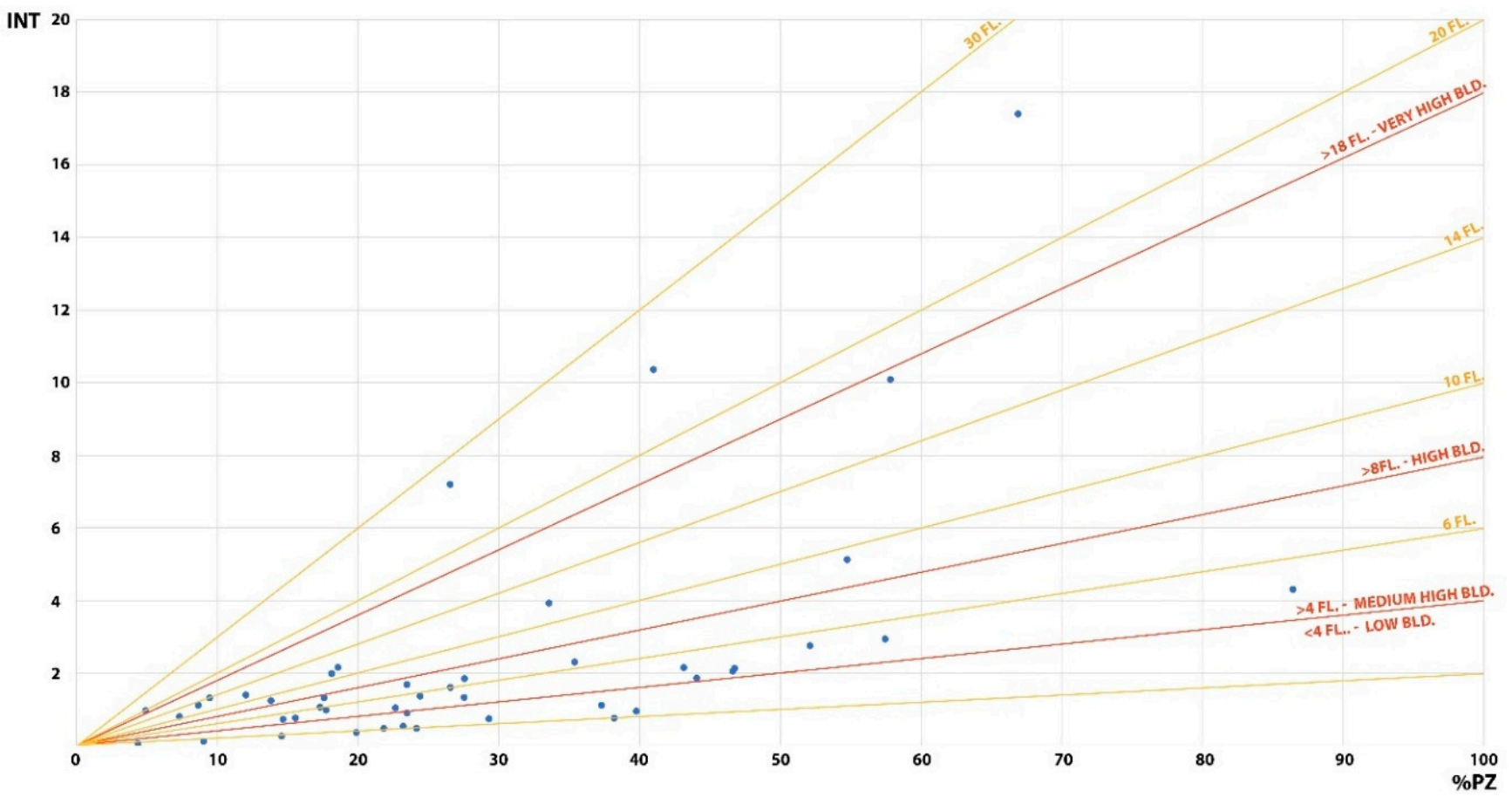

Figure 6. Distribution of INT and \%PZ values for test quarters. Source: own study.

Distribution of INT and \%PZ index values for test quarters with building types assigned

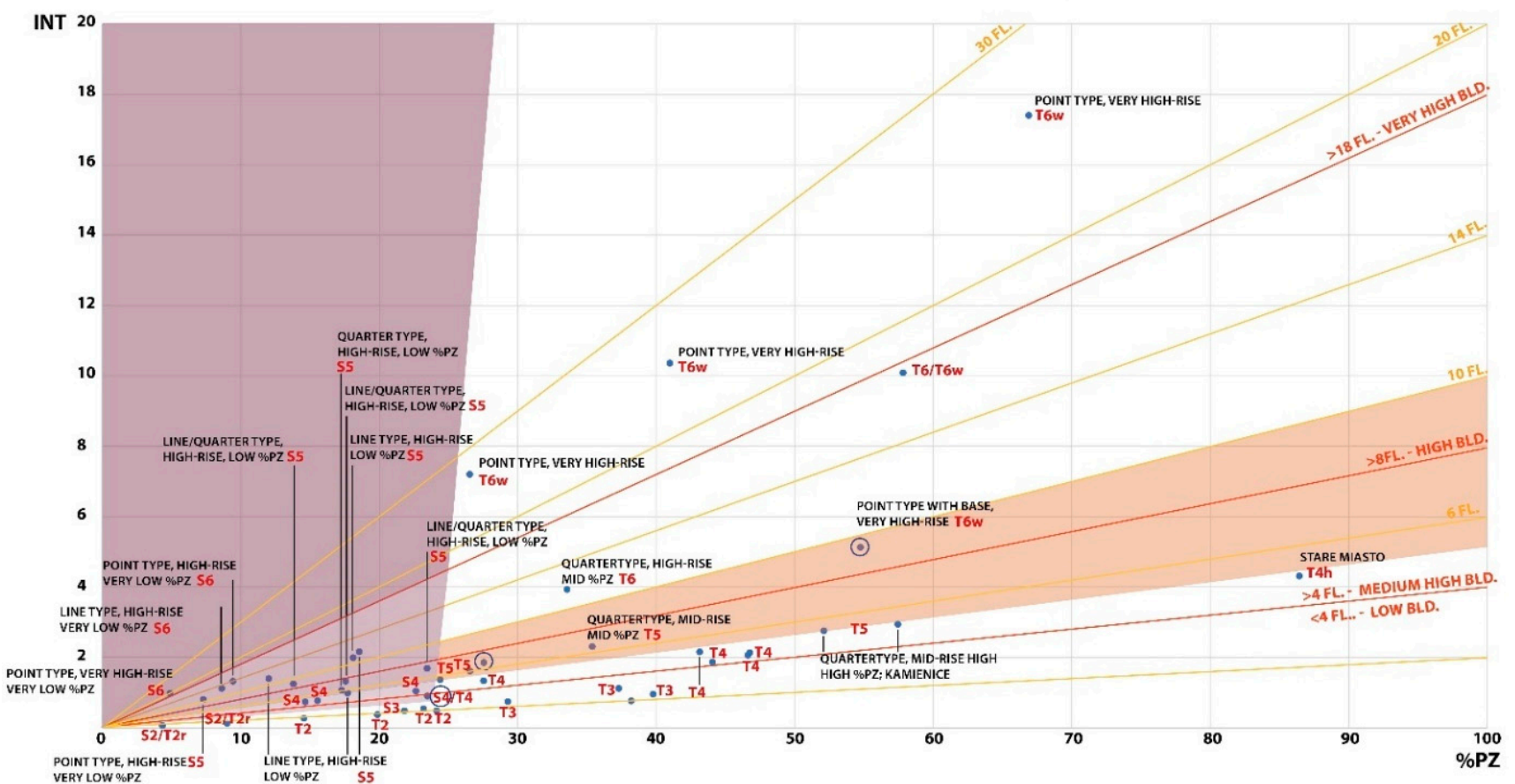

Figure 7. Distribution of INT and \%PZ index values for test quarters with building types assigned. Source: own study.

The tall freestanding towers with a higher percentage of land cover are located in the highest intensity areas-mainly located in the central part of the city. These are the quarters that will belong to the highest zones in the transect or the urban profile, i.e., to the T6 zone-called by the author of the article the high urban development zone or to the 
T6w zone-the high-rise building zone. Another type of development is mainly point or linear residential development, characterized by a high number of stories and a low rate of density and coverage. It is the type of building that includes the so-called housing estates built in the years 1958-1989. In terms of urban planning, these quarters will belong to the amorphous zones S4 or S5-low or high housing estate development zones. The former is characterized by a lower number of stories, with density and coverage values similar to the first type.

Another typology of buildings is described as quarter buildings, characterized by the fact that the quarter is filled around its perimeter. Within this typology of buildings, the division should be made not only in terms of the average number of stories characterizing the development but also by the period of its construction. In this way, two basic zones have been distinguished-T4 - urban development zone, T5-intensive urban development zone and historical subzones-T4h or T5h, which, due to historical reasons, are characterized by a high degree of coverage in the quarter-these are quarters with predominantly tenement houses.

The T3 zone is one of organized low-rise development, which is characterized by mostly semi-detached, terraced houses and city villas organized in larger layouts. In a number of amorphous zones, similar development parameters will be shown in the S3 zone-a low-scattered development zone, in which there are similar types of buildings, but their mutual arrangement in space proves a certain design defect. In this zone, there are areas with the so-called row houses, built on long, narrow strips of land, which are most often built in the peripheral areas of the city, away from other similar building structures and most often adjacent to arable fields.

Zone T2 is a zone of extensive low-rise buildings, mainly consisting of single-family detached or semi-detached houses. Similar parameter values as the T2 zone will be demonstrated by buildings in the S2 zone-known as the habitat or loose development zone, in which typical residential buildings are mixed with the remaining habitats in the areas. The zones of this development are located on the outskirts of the city and over time they are gradually transformed into more intensively developed morphological zones. The zones with the lowest index are the natural green zones-T1 or the S1 zone-the utility green zone of allotments.

For the sake of clarity of the above reading, a simplified diagram of the distribution of transect zones in the spacemate matrix for test quarters is presented below (Figure 8). It can be noticed that the lower boundaries of the transect zones were not marked on the lines marking the height of buildings, but were lowered in relation to them. This is due to the fact that these lines represent the weighted average number of stories in quarters, so if a quarter has different numbers of stories for individual buildings, and the entire quarter typologically shows the features of a given transect zone, the reduced value of the number of stories index alone will not cause an erroneous assignment of this quarter to the lower zone. It should also be noted that the boundaries between individual zones in this graph are not rigid and may change depending on a larger number of tested samples.

All the zones described above have been ranked and placed in the list of transect zones. This represents the results of module 18 from the algorithm in a graphic and understandable way, even for people who do not specialize in urban planning. For each zone, aerial photos are presented with an example of such a zone in the area of Warsaw with respective values of urban indexes characterizing the given zones (Figure 9). On this basis, it was possible not only to arrange the morphological types of buildings, but also to further the operation of the algorithm, and attempt to describe the city structure by breaking it down into transect zones.

\subsection{The Spatial Structure of Ursynów in Transect Zones}

The main aim of the article was an attempt to describe a selected part of the city by means of transect zones with the use of geographic information systems tools. Thus, initially, diagrams showing the spatial distribution of individual urban indexes for the 
study area were presented (Figure 10a-e). The following diagrams in full resolution have been attached to the article in the Attachments chapter.

Distribution of transect zones depending on the parameters of INT and \%PZ

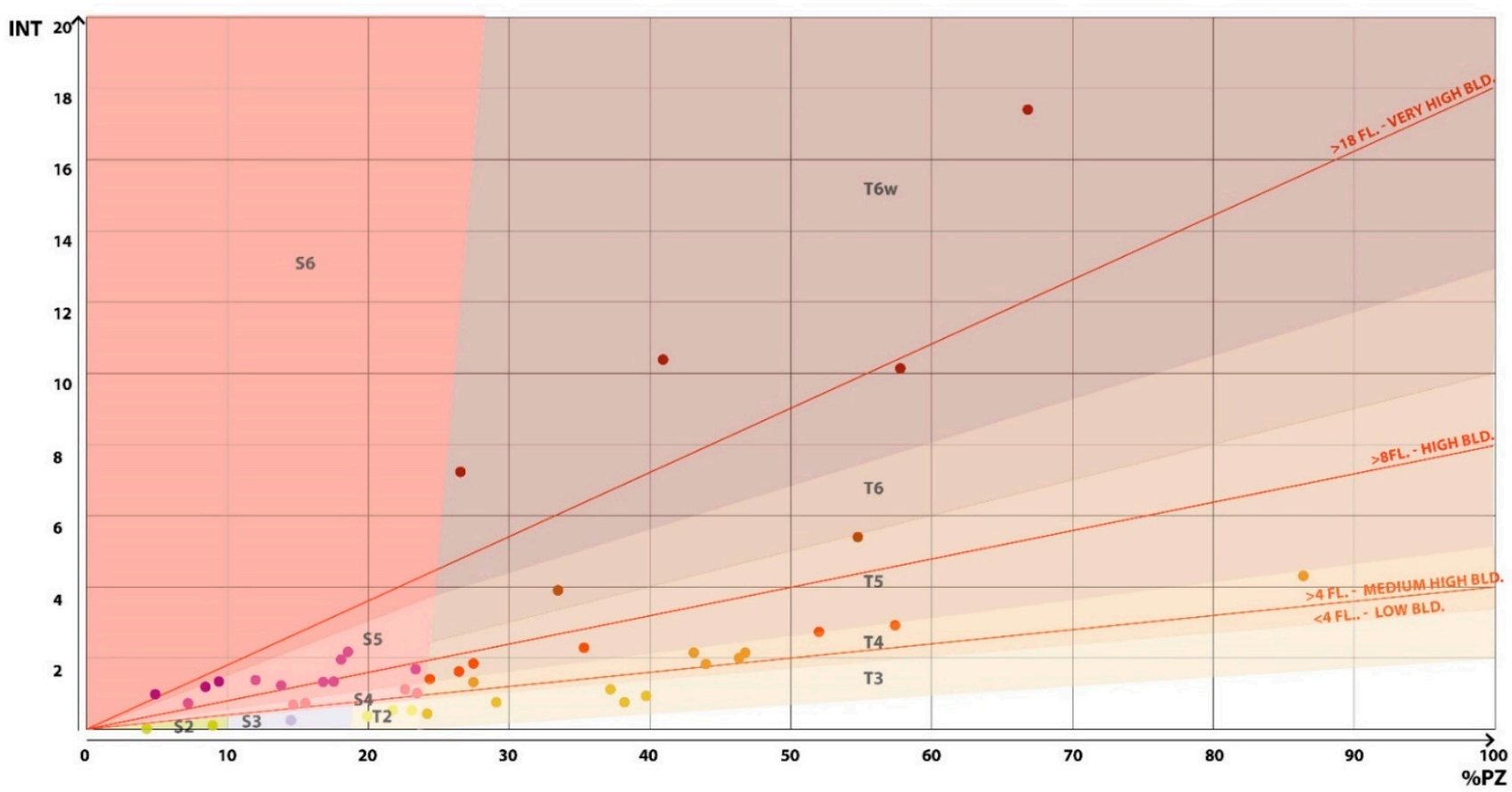

Figure 8. Distribution of building types in individual transect zones. Source: own study.

The result of applying the algorithm (modules 19 and 20) is a map showing the spatial distribution of transect zones on the selected part of the city (Figure 11 and Appendix A). Looking at the values of urban indicators for individual quarters of development, it can be noticed that they are justified by the previously discussed relationship between the values of the indexes and the typology of buildings. Housing estates, otherwise known as concrete-block, or in foreign sources park estates, are characterized by low values for land coverage and density, with a high average number of stories and a high maximum number of stories in its quarter. For this part of the city, it is a typical type of development, as this development is part of a larger layout for the whole of Ursynów, which was created on the basis of the competition design from 1971. These estates are also characterized by a large share of open spaces, free of buildings, arranged mainly as green areas between buildings and parking lots located mainly around the perimeter of the quarters. These quarters of buildings, on the basis of the indicators obtained therein and the typology of buildings, were assigned to zones S4 and S5. On the outskirts of the selected part of the city, there are quarters of buildings characterized by similar values of the average number of stories, but much higher values of the land coverage index and building density. These quarters include quarter development typical for zones T4 and T5. This development was built relatively recently and is characterized by the presence of services on the ground floors, and it is also more compact, compared to the older "park" housing estate development. The gradation of the present forms of development changes with the distance to the Vistula escarpment. Along Jana Rosoła Street there is a strip of T5 quarter buildings with an admixture of the T4 zone. Behind this strip, towards the east, predominate the lower quarter T3 development, single quarters of T4 development, and single quarters of extensive low T2 development. These development zones are also located in the northern part of the study area, between Nowoursynowska Street, Dolinka Służewiecka, and the Vistula escarpment. 

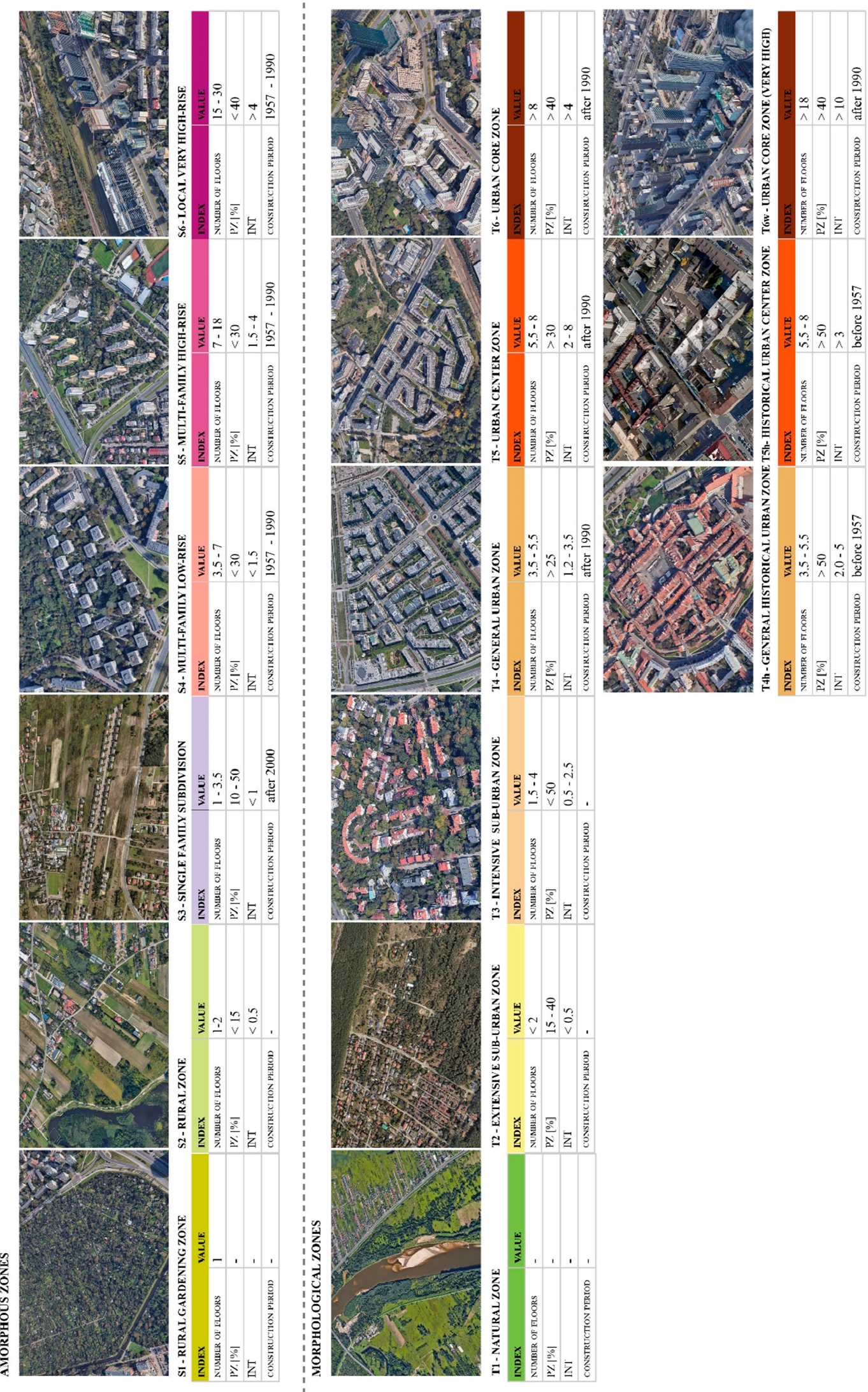

Figure 9. Transect cross-sections for the structure of the city of Warsaw. Source: own study. 


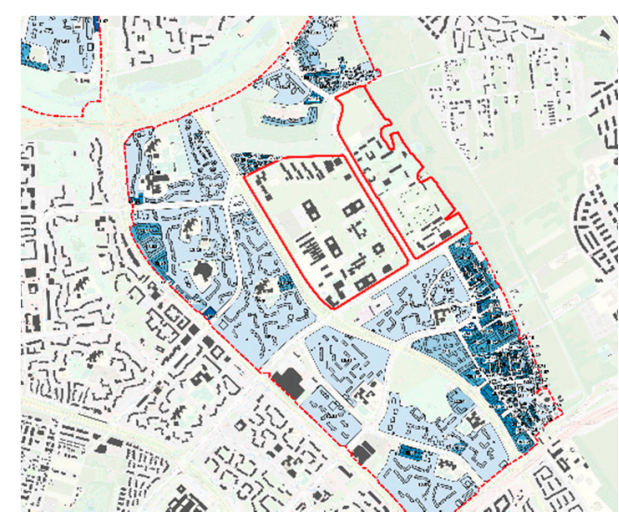

(a) Building footprint-\%PZ

Min. \% PZ -4.5

Max. \% PZ -74.7

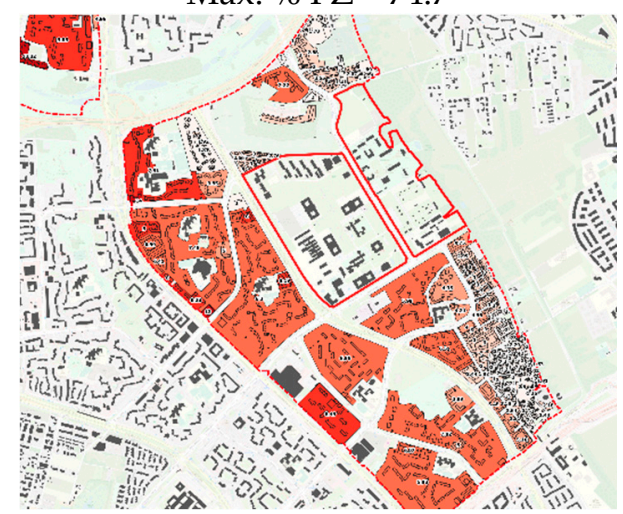

(c) Weighted average number of storeys Min. SWLK-1

Max. SWLK-14

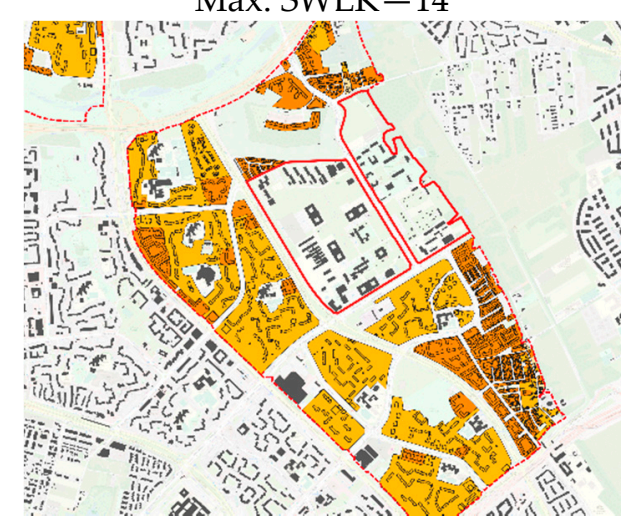

(e) Age of buildings

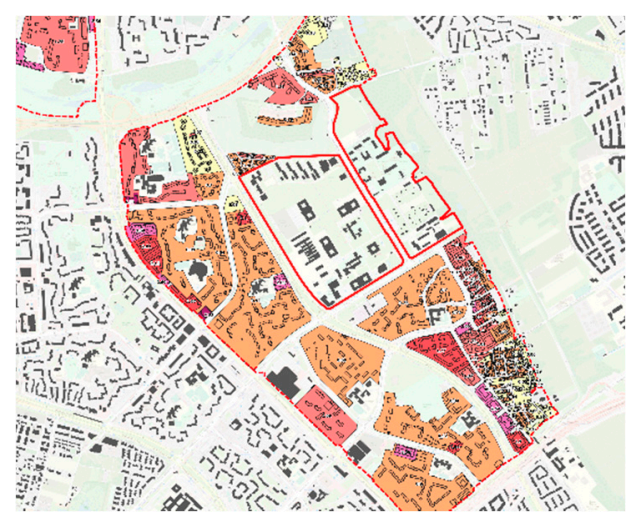

(b) Density-INT

Min. INT -0.05

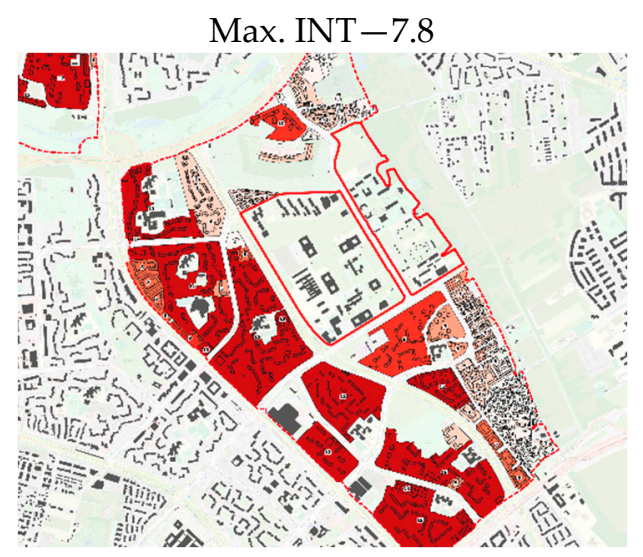

(d) Maximum number of storeys Max. H-14

Figure 10. Spatial distribution of urban indicators for the area of analysis. Source: own study. 


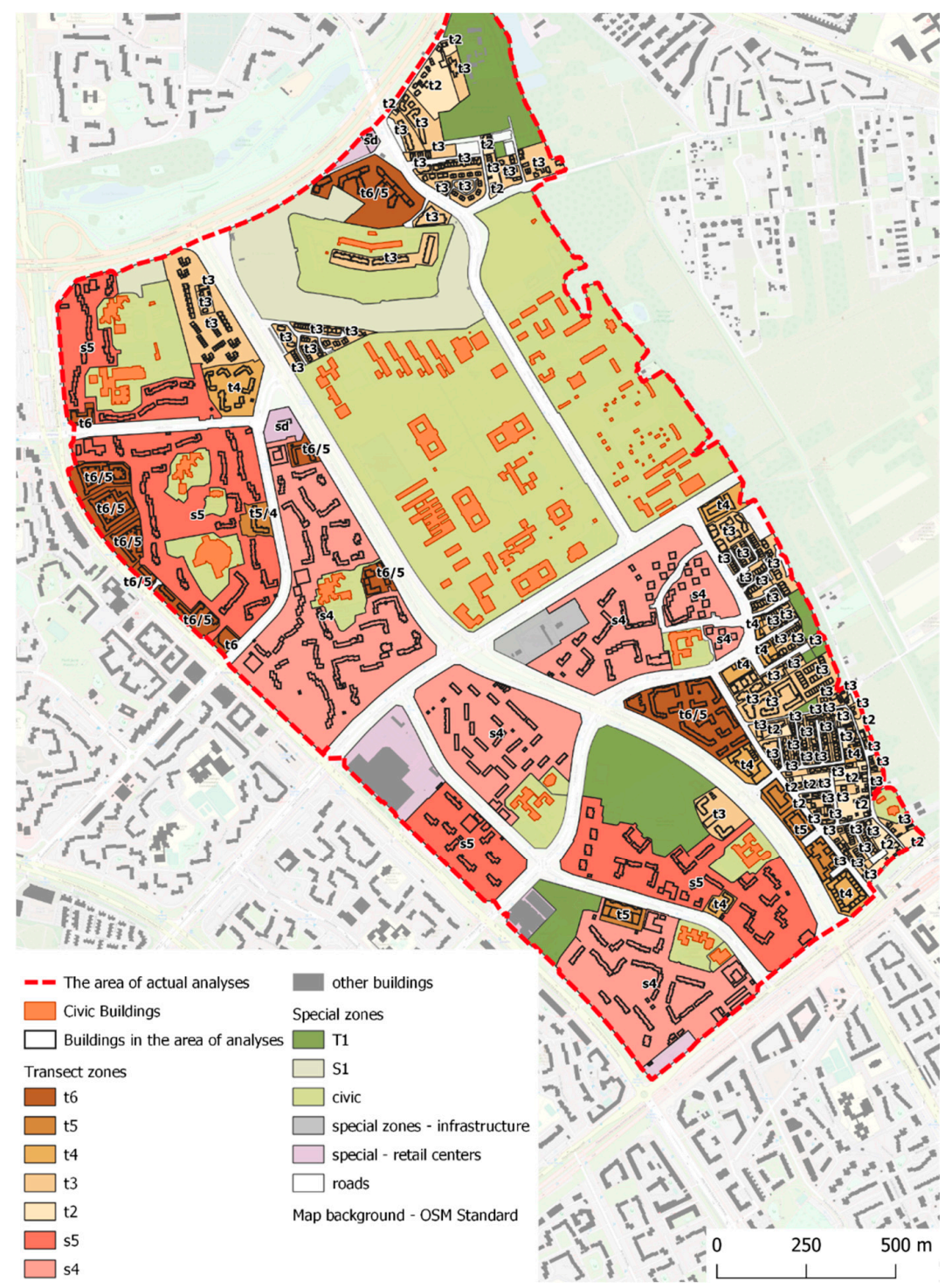

Figure 11. The urban structure of the analyzed area in transect zones. Source: own study.

\section{Conclusions}

The aforementioned example shows, the method of describing the city morphology using the transect tool certainly works for smaller parts of the city, where the automatic assignment of a building quarter to a particular transect zone can be easily verified by a human. The larger the area to be analyzed, the smaller the possibilities of precise verification of the algorithm's operation. However, for this algorithm to work flawlessly, it is essential that the input data is informative and complete. Therefore, while building the algorithm, considerable emphasis was placed on the collection, ordering, and verification of input data.

The key Issue was the possibility of introducing automation for certain tools used by urban planners through the use of geographic information systems. Thanks to this, it was possible to calculate the value of several indexes for many quarters in a relatively short time. A similarly short time was allocated to assigning individual quarters of development to the respective transect zones based on the values of selected urban indexes. It was possible thanks to iterating over the rows in the table of attributes of the calculation layer and assigning them the appropriate target.

Each introduced possibility of making calculations simultaneously on many objects significantly accelerates the performance of urban analyses for larger areas. Moreover, 
combining several geoprocessing tools into one larger one makes it possible to re-use it in the future without building it from scratch. Therefore, while the idea of how the algorithm should work and its construction may seem time-consuming, the possibility of its repeated use in the same or another part of the city makes the final average time of performing a single analysis shorter than in the case of traditional calculation of indicators for every single quarter separately. This algorithm will also be used in the author's further work on the description of the geographical morphology of the city of Warsaw.

The algorithm will be described in more detail in the author's next article, describing the technical aspects of building a tool for describing the city structure using the ruralto-urban transect profile. In addition to describing this algorithm, more emphasis will be placed on assessing its effectiveness and accuracy in several parts of various cities in Poland. This is aimed at a deeper assessment of the tool's effectiveness and to show other possibilities of its use.

Since open-source data on land coverage (BDOT10k and OSM), which is available for every city in Poland, was used for its construction, one can assume it can be used to describe the spatial structure of other cities. Therefore, the algorithm developed in this study should also be checked on fragments of other cities, in order to show its full potential for use in carrying out analyses of building morphology. When using this algorithm for other cities, the buildings of which may have different values of indicators for individual types of buildings than those assigned to the test quarters in Warsaw, the critical stage will be the verification of the adopted limit values. This stage is located between modules 19 and 18 in the algorithm. It allows for changes in the assumed parameters to be able to assign the building quarter to the appropriate transect zone as accurately as possible. An example of such verification of indexes may be the limitation of the number of transect zones when smaller cities do not have all the typologies of buildings in their structure that exist within Warsaw. Then the algorithm may omit, e.g., determining the highest zones T6, T6w, S6. Another example of introducing a change at the verification stage may be the change of the limit values for individual parameters because the buildings similarly described as quarter buildings in other urban structures may have lower indicators than the same type of buildings in Warsaw.

To sum up, the use of geoprocessing tools, including automation tools, significantly facilitates the work on urban analyses in the long term, while this is often still performed using traditional computational methods. The use of the constructed algorithm could be used not only for scientific purposes to describe the spatial structure of the city but also in practical work, when performing urban analyses at the diagnostic stage of preparing local spatial development plans or when checking the urban parameters of the neighboring buildings when issuing decisions on building development conditions.

In the literature, examples of urban indicators or object-oriented programming for research on the structuring of space have been found [50]. However, there is a lack of similar research on combining the transect and spacemate methods, especially to describe the city structure or the dynamically changing city landscape, which may be a novelty in urban planning and the parameterization of the transect itself using GIS systems. The proposed spatial description tool also enables the assessment of how the landscape of a selected part of the city has changed over the years. It is crucial when assessing the dynamics of a city's development or creating a policy of its development caused by various factors, e.g., environmental or economic.

Funding: This research was funded by IDUB against COVID-19 project granted by Warsaw University of Technology under the program Excellence Initiative: Research University (IDUB). (Warsaw University of Technology, grant number: 504/04496/1010/).

Institutional Review Board Statement: Not applicable.

Informed Consent Statement: Not applicable. 
Data Availability Statement: The results of the work will be available for viewing on the website www.warsawobservatory.eu (accessed on 15 November 2021).

Conflicts of Interest: The authors declare no conflict of interest.

\section{Appendix A}

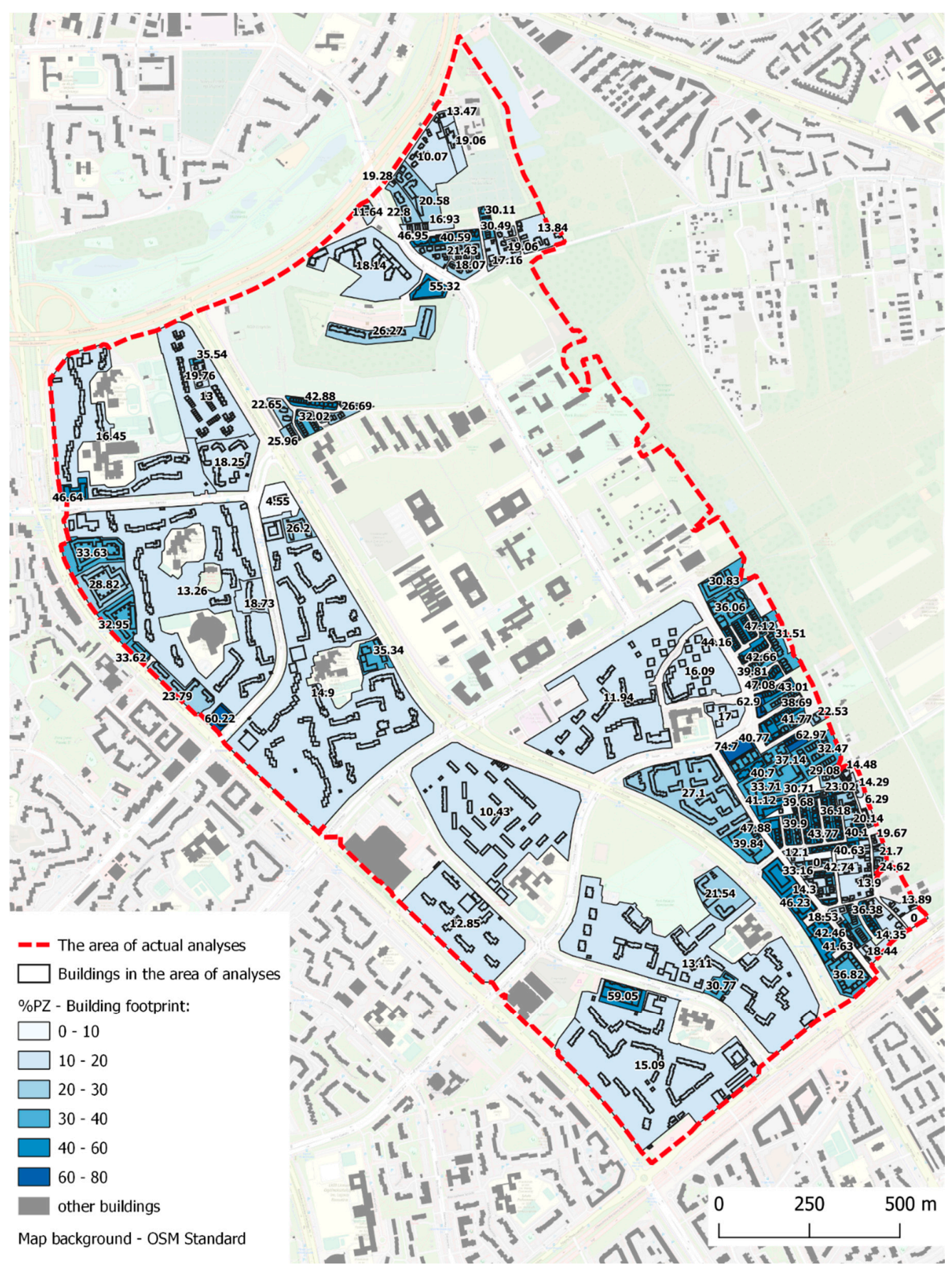

Figure A1. Building Footprint-\%PZ. 


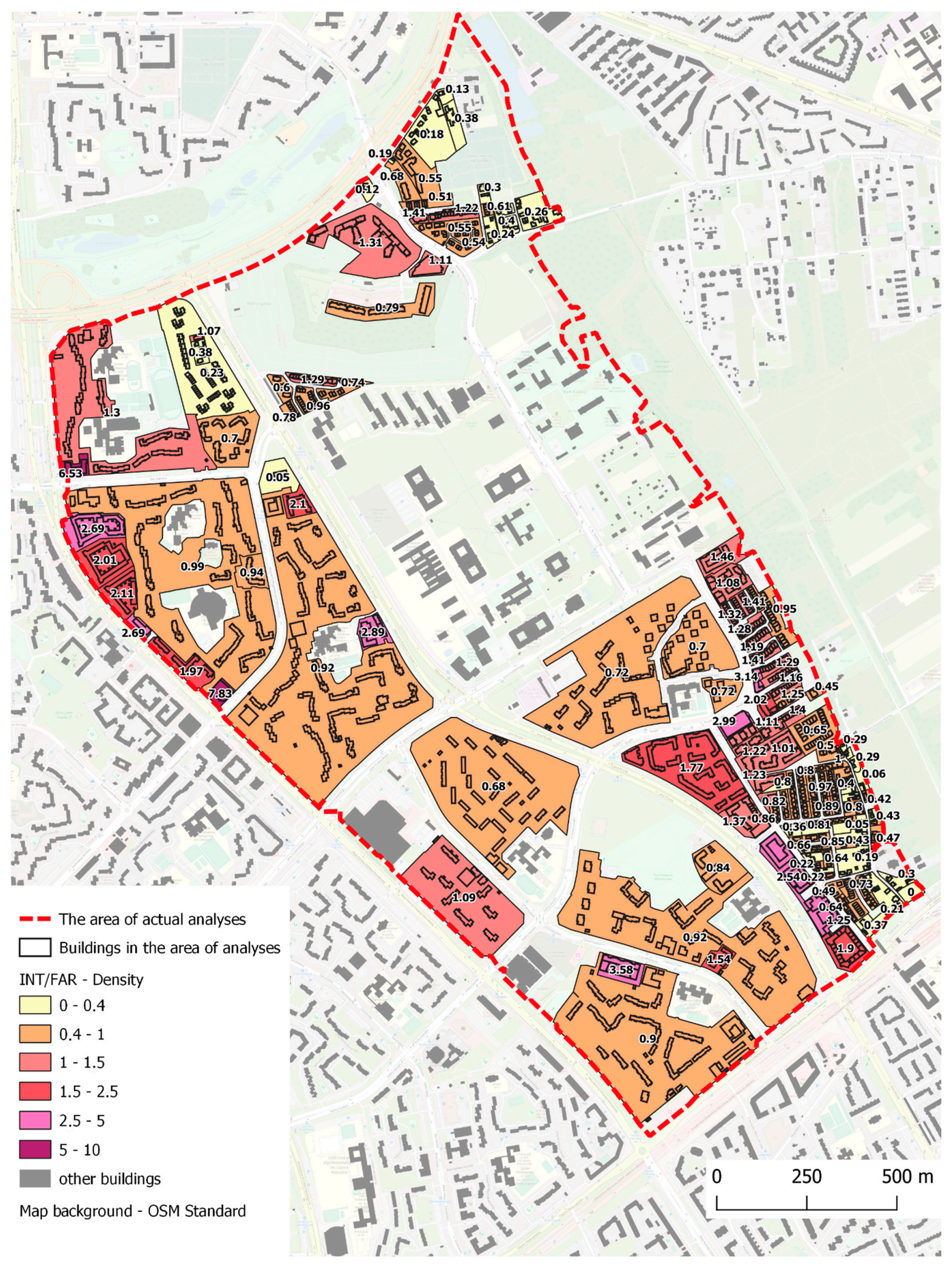

Figure A2. Density-INT. 


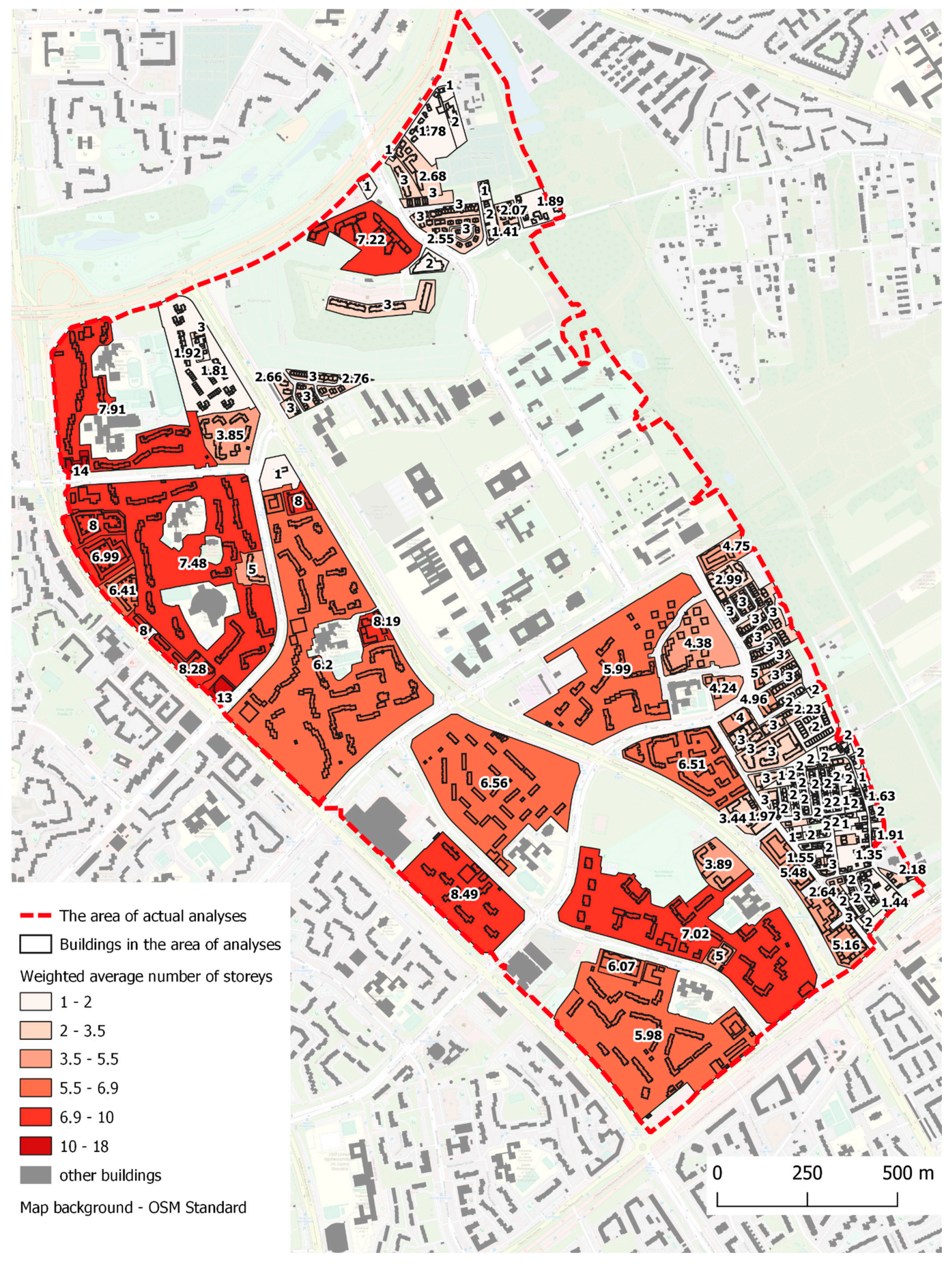

Figure A3. Weighted average number of storeys-SWLK. 


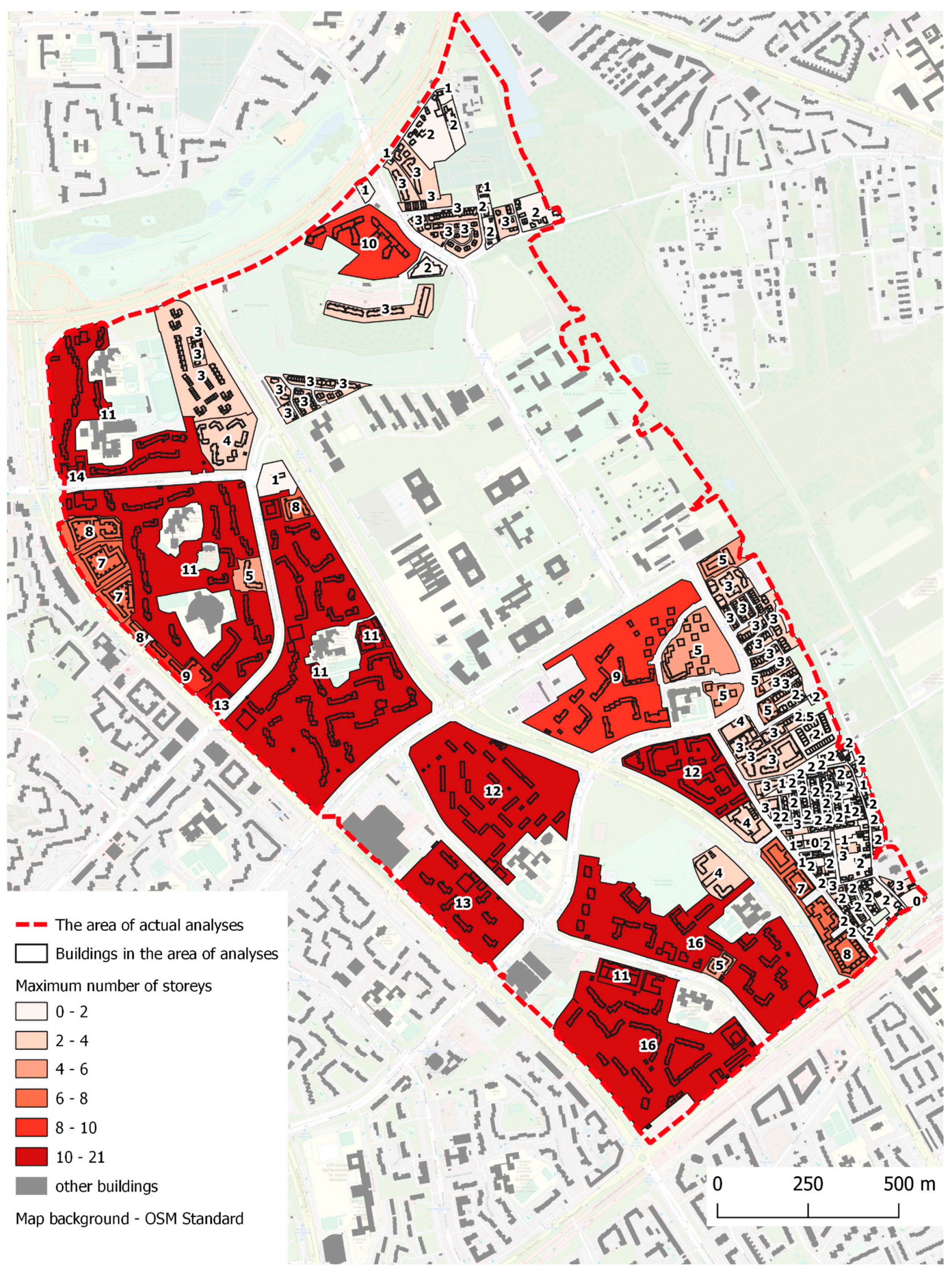

Figure A4. Maximum number of storeys-max.H. 


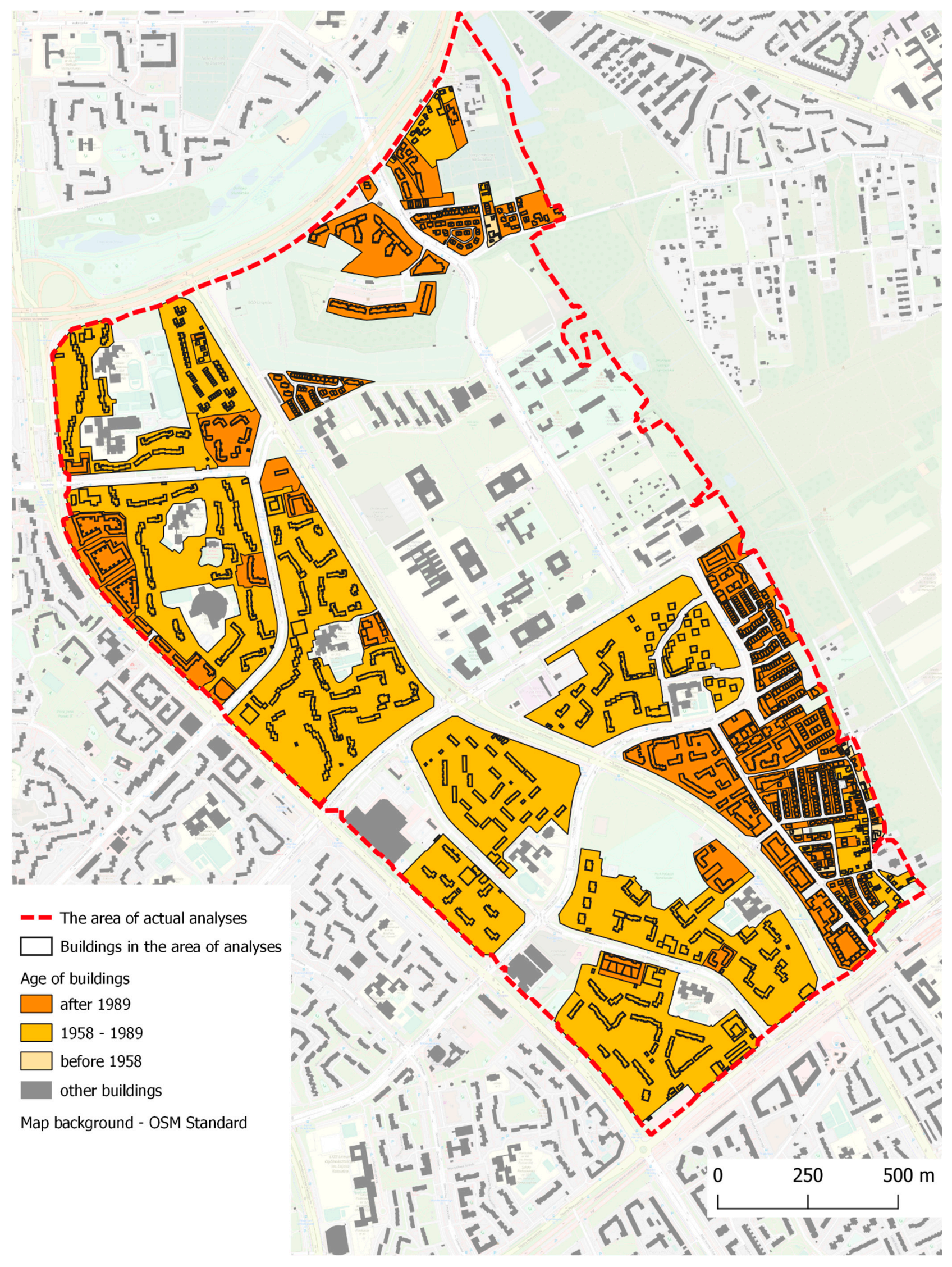

Figure A5. Age of buildings. 


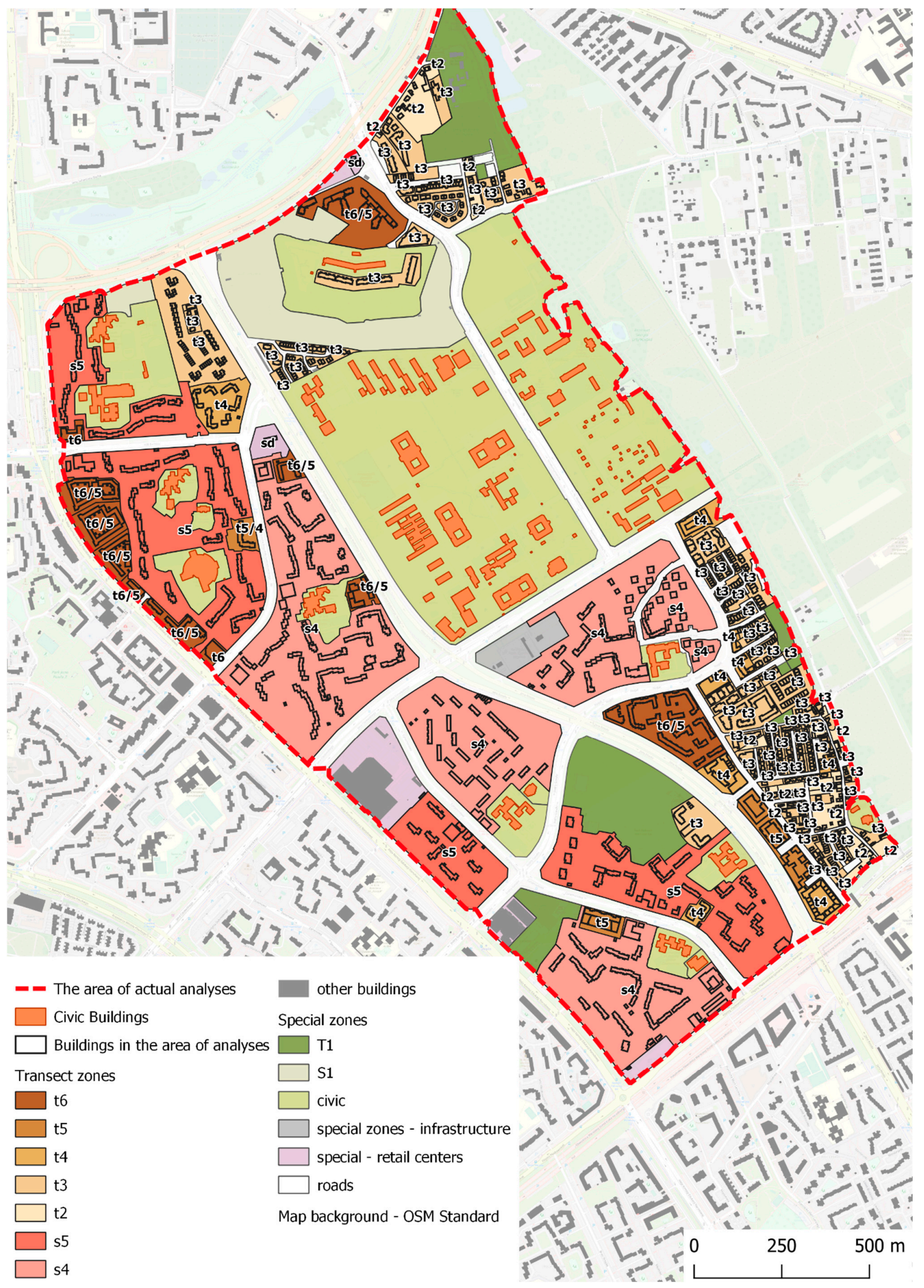

Figure A6. The urban structure of the analysed area in transect zones. 


\section{References}

1. Słownik Języka Polskiego. Available online: https://sjp.pl/struktura (accessed on 1 May 2021).

2. Solarek, K. Struktura Przestrzenna Strefy Podmiejskiej Warszawy; Oficyna Wydawnicza Politechniki Warszawskiej: Warsaw, Poland, 2013 ; p. 26.

3. Sumień, T. Forma Miasta Kontekst i Anatomia; CPBR Instytut Gospodarki Przestrzennej i Komunalnej: Warsaw, Poland, $1992 ;$ p. 38.

4. Liszewski, S. Geografia Urbanistyczna; Wydawnictwo Naukowe PWN: Warsaw, Poland, 2012.

5. Fiedorowicz, J. Kształtowanie struktury przestrzennej miasta zrównoważonego. Zesz. Nauk. Archit. Politech. Ślaska 2012, 51, 117-132.

6. Słownik Języka Polskiego. Available online: https://sjp.pl/strefa (accessed on 1 May 2021).

7. Podolak, S., XV. Podstawowe Pojęcia i Definicje. In Gospodarka Przestrzenna Gmin. Poradnik, t.III; Podolak, S., Ed.; IGPiK O/Kraków, Llewelyn-Davis: London, UK; Fundusz Współpracy: Brytyjski Fundusz “Konw-How”: Kraków, Poland, 1998 ; p. 300.

8. Drzazga, D. Systemowe Uwarunkowania Planowania Przestrzennego Jako Instrumentu Osiagania Sustensywnego Rozwoju; Wydawnictwo Uniwersytetu Łódzkiego: Łódź, Poland, 2018; pp. 234-242.

9. Zuziak, Z.K. Strefowanie Przez Standardy w Planach Miejscowych Zagospodarowania Przestrzennego. In Człowiek i Środowisko. Gospodarka Przestrzenna i Komunalna; Instytut Gospodarki Przestrzennej i Komunalnej: Warsaw, Poland, 1998; Volume 22, No 1-2; pp. $87-88$.

10. Podolak, S., XV. Podstawowe Pojęcia i Definicje. In Gospodarka Przestrzenna Gmin. Poradnik, t.III; Podolak, S., Ed.; IGPiK O/Kraków, Llewelyn-Davis: London, UK; Fundusz Współpracy: Brytyjski Fundusz “Konw-How”: Kraków, Poland, 1998 ; p. 301.

11. Grudziński, A. Standard urbanistyczny zabudowy mieszkaniowej. In Człowiek i Środowisko. Gospodarka Przestrzenna i Komunalna; Instytut Gospodarki Przestrzennej i Komunalnej: Warsaw, Poland, 1998; Volume 22, No 1-2; pp. 95-96.

12. Dabrowska-Milewska, G. Standardy urbanistyczne dla terenów mieszkaniowych-Wybrane zagadnienia. In Architecturae et Artibus; Oficyna Wydawnicza Politechniki Białostockiej: Białystok, Poland, 2010; pp. 17-31.

13. Ziobrowski, Z. Urbanistyczne Wymiary Miast; Instytut Rozwoju Miast: Kraków, Poland, 2012.

14. Waibel, M.; Eckert, R.; Bose, M.; Martin, V. Housing for Low-Income Groups in Ho Chi Minh City between Re-Integration and Fragmentation Approaches to Adequate Urban Typologies and Spatial Strategies. ASIEN Ger. J. Contemp. Asia 2007, $103,59-78$.

15. UrbiumetOrbi Blog, Relation between Building Typologies \& Density. Available online: https://urbiumetorbi.wordpress.com/20 15/07/10/building-typologies-and-density-by-richard-rogers (accessed on 20 October 2021).

16. Berghauser Pont, M.B.; Haupt, P. Spacemate: The Spatial Logic of Urban Density; Delft University Press: Delft, The Netherlands, 2004.

17. Berghauser Pont, M.B.; Haupt, P. The relation between urban form and density. J. Urban Morphol. 2007, 11, 62-64.

18. Berghauser Pont, M.B.; Haupt, P. Space Matrix: Space, Density and Urban Form; NAi.: Rotterdam, The Netherlands, 2010.

19. Center for Applied Transect Studies. Available online: https://transect.org/index.html (accessed on 28 August 2021).

20. Domińczak, M. Nowa Urbanistyka. In Metodyka i Zasady Projektowania Według SmartCode; Wydawnictwo Politechniki Łódzkiej: Łódź, Poland, 2020.

21. Talen, E. Help for Urban Planning: The Transect Strategy. J. Urban Plan. 2002, 7, 293-312. [CrossRef]

22. Center for Applied Transect Studies. Available online: https://transect.org/codes.html (accessed on 28 August 2021).

23. Solarek, K. Urban Design in Town Planning; Oficyna Wydawnicza Politechniki Warszawskiej: Warsaw, Poland, 2019.

24. Lotfi, S.; Sholeh, M.; Tabrizi, T. The Application of Transect as a Tool for Urban Landscape Zoning and the Redefinition of the Built Environment Formal Hierarchy. Urban Plan. Knowl. 2019, 2, 95-113. [CrossRef]

25. Brower, S. The Sectors of the Transect. J. Urban Des. 2002, 7, 313-320. [CrossRef]

26. Wadduwage, S.; Millington, A.; Crossman, N.D.; Sandhu, H. Agricultural Land Fragmentation at Urban Fringes: An Application of Urban-To-Rural Gradient Analysis in Adelaide. Land 2017, 6, 28. [CrossRef]

27. Vizzari, M.; Sigura, M. Landscape sequences along the urban-rural-natural gradient: A novel geospatial approach for identification and analysis. Landsc. Urban Plan. 2015, 140, 42-55. [CrossRef]

28. Zhang, Y.; Liu, C. Parametric Modeling for Form-Based Planning in Dense Urban Environments. Sustainability 2019, 11, 5678. [CrossRef]

29. Talen, E. SmartCode Justice. Places 2006, 18. Available online: https://placesjournal.org/assets/legacy/pdfs/smartcode-justice. pdf (accessed on 20 December 2021).

30. Duany, A.; Talen, E. Transect Planning. J. Am. Plan. Assoc. 2002, 68, 245-266. [CrossRef]

31. Stylianidis, E.; Karanikolas, N.; Kaimaris, D. A GIS for urban sustainability indicators on spatial planning. Int. J. Sustain. Dev. Plan. 2012, 7, 1-13. [CrossRef]

32. Szylar, M.; Cegielska, K.; Kukulska-Kozieł, A. Application of gis tools for spatial planning analysis. Pr. Studia Geogr. 2019, 63, 81-99.

33. Gotlib, D.; Olszewski, R.; Iwaniak, A. GIS, Obszary Zastosowań; Wydawnictwo Naukowe PWN: Warsaw, Poland, 2007.

34. Kraak, M.J.; Ormeling, F. Cartography. In Visualization of Geospatial Data, 4th ed.; CRC Press: Boca Raton, FL, USA, 2021.

35. Fogel, P. Wspomaganie procesu tworzenia polityki przestrzennej w gminie poprzez wykorzystanie prostych analiz GIS. In Acta Universitatis Lodziensis. Folia Geographica Socio-Oeconomica; Wydawnictwo Uniwersytetu Łódzkiego: Łódź, Poland, 2013; Volume 14.

36. Głowacka, A.; Pluta, M. The application of GIS in spatial planning. Geomat. Landmanag. Landsc. 2016, 3, 49-56. [CrossRef] 
37. Mondal, B.; Das, D.N.; Bhatta, B. Integrating cellular automata and Markov techniques to generate urban development potential surface: A study on Kolkata agglomeration. Geocarto Int. 2016, 32, 401-419. [CrossRef]

38. Cegielska, K.; Salata, T.; Szylar, M.; Kudas, D. Ocena potencjału inwestycyjnego gminy Skała przy wykorzystaniu narzędzi GIS, EPISTEME. Czas. Nauk.-Kult. 2016, 30, 349-363.

39. Musiaka, Ł.; Nalej, M. Application of GIS Tools in the Measurement Analysis of Urban Spatial Layouts Using the Square Grid Method. ISPRS Int. J. Geo-Inf. 2021, 10, 558. [CrossRef]

40. Solarek, K.; Jachimowicz, A.M. A land capacity analysis method using GIS tools, as exemplified by the City of Warsaw, Poland. In Spaces of Dialog for Places of Dignity: Fostering the European Dimension of Planning; Freitas, C., Fonseca, I., Eds.; Universidade de Lisboa: Lisbon, Portugal, 2017; pp. 2707-2718. ISBN 978-989-99801-3-6.

41. Murshed, S.M.; Duval, A.; Koch, A.; Rode, P. Impact of Urban Morphology on Energy Consumption of Vertical Mobility in Asian Cities-A Comparative Analysis with 3D City Models. Urban Sci. 2019, 3, 4. [CrossRef]

42. Jachimowicz, A.M. Baza Danych Przestrzennych Jako Narzędzie Działań Partycypacyjnych na Terenie Miasta Warszawy. In Rola Partycypacji Społecznej w Ksztattowaniu Miast; Mirecka, M., Ed.; Oficyna Wydawnicza Politechniki Warszawskiej: Warsaw, Poland, 2021.

43. Duany, A. Transect Urbanism: Readings in Human Ecology; ORO Editions: Novato, CA, USA, 2020.

44. ESRI. Available online: https://www.esri.com/en-us/what-is-gis/overview (accessed on 1 May 2021).

45. Główny Urząd Geodezji i Kratografii. Available online: http://www.gugik.gov.pl/projekty/zsin-faza-i/dane-egib (accessed on 30 April 2021).

46. Miasto Stołeczne Warszawa, Dane do Pobrania. Available online: https:/ / mapa.um.warszawa.pl/BGIK/ (accessed on 1 May 2021).

47. OpenStreetMap. Available online: https://www.openstreetmap.org/about (accessed on 1 May 2021).

48. Geoportal Infrastruktury Informacji Przestrzennej. Available online: https://www.geoportal.gov.pl/dane/baza-danychobiektow-topograficznych-bdot (accessed on 1 May 2021).

49. Rozporządzenie Ministra Infrastruktury z Dnia 12 Kwietnia 2002 r. w Sprawie Warunków Technicznych, Jakim Powinny Odpowiadać Budynki i Ich Usytuowanie. Dz.U.2019.0.1065. Available online: http://isap.sejm.gov.pl/isap.nsf/download.xsp/ WDU20190001065/O/D20191065.pdf (accessed on 4 April 2021).

50. Jania, M. Struktura urbanistyczna Smart City. Przestrz. Urban. Archit. 2017, 2, 57-83. [CrossRef] 